\title{
Prevalence of Burnout in Medical and Surgical Residents: A Meta-Analysis
}

\author{
Zhi Xuan Low ${ }^{1}$, Keith A. Yeo ${ }^{1}$, Vijay K. Sharma ${ }^{2}{ }^{\oplus}$, Gilberto K. Leung ${ }^{3}$, Roger S. McIntyre ${ }^{4,5,6,7}$, \\ Anthony Guerrero ${ }^{8}{ }^{D}$, Brett Lu ${ }^{8}$, Chun Chiang Sin Fai Lam ${ }^{9}$, Bach X. Tran 10,11,12, \\ Long H. Nguyen ${ }^{13}$, Cyrus S. Ho ${ }^{14}$, Wilson W. Tam ${ }^{15}$ iD and Roger C. Ho $1,16,17, *(\mathbb{D})$
}

1 Department of Psychological Medicine, Yong Loo Lin School of Medicine, National University of Singapore, Singapore 119228, Singapore; a0133292@u.nus.edu (Z.X.L.); a0133415@u.nus.edu (K.A.Y.)

2 Department of Medicine, Yong Loo Lin School of Medicine, National University of Singapore, Singapore 119228, Singapore; mdcvks@nus.edu.sg

3 Department of Surgery, The University of Hong Kong, Hong Kong, China; gilberto@hku.hk

4 Institute of Medical Science, University of Toronto, Toronto, ON M5S 1A8, Canada; Roger.McIntyre@uhn.ca

5 Mood Disorders Psychopharmacology Unit, University Health Network, Toronto, ON M5G 2C4, Canada

6 Department of Psychiatry, University of Toronto, Toronto, ON M5T 1R8, Canada

7 Department of Toxicology and Pharmacology, University of Toronto, Toronto, ON M5S 1A8, Canada

8 Department of Psychiatry, John A Burns School of Medicine, University of Hawaii, Honolulu, HI 96813, USA; GuerreroA@dop.hawaii.edu (A.G.); brettlu@yahoo.com (B.L.)

9 South London and Maudsley NHS Foundation Trust, London SE5 8AZ, UK; sinfailamcc@googlemail.com

10 Institute for Preventive Medicine and Public Health, Hanoi Medical University, Hanoi 100000, Vietnam; bach@jhu.edu

11 Department of Health, Behavior and Society, Johns Hopkins Bloomberg School of Public Health, Baltimore, MD 21205, USA

12 Vietnam Young Physicians' Association, Hanoi 100000, Vietnam

13 Institute for Global Health Innovations, Duy Tan University, Da Nang 550000, Vietnam; long.ighi@gmail.com

14 Department of Psychological Medicine, National University Hospital, Singapore 119228, Singapore; su_hui_ho@nuhs.edu.sg

15 Alice Lee School of Nursing, Yong Loo Lin School of Medicine, National University of Singapore, Singapore 117597, Singapore; nurtwsw@nus.edu.sg

16 Biomedical Institute for Global Health Research and Technology, National University of Singapore, Singapore 119228, Singapore

17 Centre of Excellence in Behavioral Medicine, Nguyen Tat Thanh University (NTTU),

Ho Chi Minh City 70000, Vietnam

* Correspondence: pcmrhcm@nus.edu.sg

Received: 10 March 2019; Accepted: 23 April 2019; Published: 26 April 2019

\begin{abstract}
The burnout syndrome is characterized by emotional exhaustion, depersonalization, and reduced personal achievement. Uncertainty exists about the prevalence of burnout among medical and surgical residents. Associations between burnout and gender, age, specialty, and geographical location of training are unclear. In this meta-analysis, we aimed to quantitatively summarize the global prevalence rates of burnout among residents, by specialty and its contributing factors. We searched PubMed, PsycINFO, Embase, and Web of Science to identify studies that examined the prevalence of burnout among residents from various specialties and countries. The primary outcome assessed was the aggregate prevalence of burnout among all residents. The random effects model was used to calculate the aggregate prevalence, and heterogeneity was assessed by $\mathrm{I}^{2}$ statistic and Cochran's Q statistic. We also performed meta-regression and subgroup analysis. The aggregate prevalence of burnout was 51.0\% (95\% CI: 45.0-57.0\%, $\left.\mathrm{I}^{2}=97 \%\right)$ in 22,778 residents. Meta-regression found that the mean age $(\beta=0.34,95 \% \mathrm{CI}: 0.28-0.40, p<0.001)$ and the proportion of males $(\beta=0.4$, $95 \%$ CI $=0.10-0.69, p=0.009)$ were significant moderators. Subgroup analysis by specialty showed that radiology (77.16\%, 95\% CI: 5.99-99.45), neurology (71.93\%, 95\% CI: 65.78-77.39), and general
\end{abstract}


surgery (58.39\%, 95\% CI: 45.72-70.04) were the top three specialties with the highest prevalence of burnout. In contrast, psychiatry (42.05\%, 95\% CI: 33.09-51.58), oncology (38.36\%, 95\% CI: 32.69-44.37), and family medicine (35.97\%, 95\% CI: 13.89-66.18) had the lowest prevalence of burnout. Subgroup analysis also found that the prevalence of burnout in several Asian countries was $57.18 \%$ (95\% CI: 45.8-67.85); in several European countries it was $27.72 \%$ (95\% CI: 17.4-41.11) and in North America it was $51.64 \%$ (46.96-56.28). Our findings suggest a high prevalence of burnout among medical and surgical residents. Older and male residents suffered more than their respective counterparts.

Keywords: burnout; junior doctors; medical; meta-analysis; prevalence; residency; surgical

\section{Introduction}

The term "burnout" was first defined by Freudenberger to describe the emotional exhaustion experienced by civil servants [1]. The three main components of burnout are an overwhelming exhaustion, feelings of cynicism or depersonalization, and a sense of ineffectiveness and lower efficacy [2-4]. The processual character of burnout refers to cumulative negative consequences of long-term work-related stress as a result of exhaustion [5]. In clinical settings, evidence shows that burnout causes prescription errors [6] and reduces the quality of medical services [7-9], potentially affecting inter-professional relationship [10,11]. Burnout is a precipitating factor for depression [12] and substance abuse [13] among medical professionals. It is also one of the most common mental health issues faced by medical and surgical residents or trainees who are junior doctors holding Bachelor of Medicine and Bachelor of Surgery or undergraduate Doctor of Medicine degrees and who are undergoing supervised medical or surgical specialty training. Burnout contributes to poor job satisfaction [14] and a negative impact on their mental and physical health [15,16]. In recent years, the risk of residents developing burnout has been further aggravated by increasing peer competition, clinical and administrative loads, medical litigation, and expectations of training [17]. However, this is often overlooked by clinical supervisors and hospital administration.

Although burnout among residents remains under-recognized, many important issues are open for debate. First, the global prevalence of burnout in residents is unclear due to different working conditions in various medical and surgical specialties. Previous reviews focused on the prevalence rates of burnout syndrome in a single specialty $[18,19]$. Second, variations have been reported in the prevalence rates of burnout, ranging from $18.7 \%$ to $74.8 \%$, mainly due to different assessment methods and small sample sizes [20]. Third, the influence of demographic variables (e.g., sex, age, geographic region) on burnout rates has not been adequately tested. As a result, there is a strong justification for conducting research on the prevalence of burnout. In this meta-analysis, we aimed to synthesize data on the prevalence of burnout in residents from various specialties in different world regions. Furthermore, in this study, we evaluated the demographic and geographical moderators which might facilitate better identification of residents at risk and guide health authorities when they plan optimal preventive interventions.

\section{Materials and Methods}

\subsection{Search Strategy and Selection Criteria}

The literature search and the review protocol were designed and performed in accordance with the Preferred Reporting Items for Systematic Reviews and Meta-Analyses (PRISMA) statement [21]. A systematic search using PubMed, PsycINFO, Embase, and Web of Science was independently conducted by two authors (Z.X.L. and K.A.Y.), from inception to March 2018. The search was done with Boolean operators "AND" and "OR", and with all possible combinations of the Medical Subject Heading (MeSH) terms: residents, trainees, burnout, burn-out, burn out, medical, medicine, 
internal medicine, general surgery, surgery, surgical, radiology, radiological, neurology, neurological, orthopaedics, orthopedics, orthopaedic, orthopedic, dermatology, obstetrics, obstetric, gynecology, gynaecology, gynecological, gynaecological, neurosurgery, neurosurgical, paediatrics, pediatrics, paediatric, pediatric, anaesthesia, anesthesia, anaesthesiology, anesthesiology, otolaryngology, ear nose and throat, ENT, psychiatry, psychiatric, oncology, oncological, family medicine, emergency medicine, accident and emergency, and ophthalmology and ophthalmological. Back-referencing was used to identify potential studies and relevant citations to be included in our analysis.

\subsection{Inclusion and Exclusion Criteria}

Study inclusion criteria were as follows: observational cohort and cross-sectional studies that reported the prevalence of burnout among medical residents and the measurement of burnout using the Maslach Burnout Inventory (MBI) [22]. Burnout is a long-term stress reaction marked by emotional exhaustion, depersonalization, and a lack of sense of personal accomplishment [23]. Medical/surgical residents or trainees were defined as junior doctors who possessed basic medical degrees such as Bachelor of Medicine (MB), Bachelor of Medicine and Surgery (MBBS, MBChB, or equivalent), or Doctor of Medicine (MD) and who were undergoing supervised training. Other professionals such as senior physicians, chiropractors, and medical students were excluded. We also excluded studies that had missing or unavailable data, such as the specialty being studied, the number of residents who experienced burnout, or the prevalence of burnout. Finally, systematic reviews, commentaries, editorial articles, and publications that were not written in English were also excluded.

\subsection{Data Extraction and Quality Assessment}

We used a standard data collection form to record study characteristics, participant demographics, and various results. The primary outcome of our meta-analysis was the prevalence of burnout in a particular group of residents being studied. Two co-authors (Z.X.L. and K.A.Y.) independently extracted the data. Disagreements were resolved by discussion with the last author (R.C.H.).

The methodological quality assessment of the included studies was performed with the National Institutes of Health's Quality Assessment Tool for Observational Cohort and Cross-Sectional Studies (NIH-QAT) [24] (See Appendix A). This tool helps researchers to assess various aspects of a study and assign an overall quality rating of "Good", "Fair", or "Poor". The assessment criteria include clarity of the research question, consistency of study population and eligibility criteria, justification of sample size, outcome measurement; duration of outcome measurement and follow-ups, and quality of statistical analyses.

\subsection{Statistical Analyses}

Statistical analyses were conducted with the "metafor" function of the software R (R Core Team, Vienna, Austria, 2013). We calculated prevalence rates of burnout based on the crude numerators (i.e., the number of residents who met burnout criteria) and denominators (i.e., total number of residents) provided by individual studies. The random effects model generalizes findings beyond the included studies by assuming that the selected studies are random samples from a larger population [25]. A random effects model was used to calculate the aggregate prevalence of burnout and $95 \%$ confidence intervals (CIs) [26]. Heterogeneity was examined by Cohen's Q statistic and $\mathrm{I}^{2}$ statistic [27]. As a guide, $\mathrm{I}^{2}$ values of $25 \%$ may be considered low, $50 \%$ moderate, and $75 \%$ high [28]. In the presence of high heterogeneity, we used the random effects model which is deemed most appropriate [29]. Furthermore, we performed meta-regression to assess the influence of different study factors on the aggregate prevalence of burnout [30]. Egger's regression test was performed to assess for the presence of publication bias [31]. Subgroup analyses were conducted to explore the source of heterogeneity among subgroups-by specialty and geographical region. 


\section{Results}

\subsection{Characteristics of Studies}

Our search strategy identified 676 potentially eligible studies. We screened the titles and abstracts and excluded 493 irrelevant articles due to various pre-defined criteria. The full texts of the remaining 183 articles were assessed for eligibility, of which 136 were excluded (Figure 1). Finally, 47 articles were included in the meta-analysis.

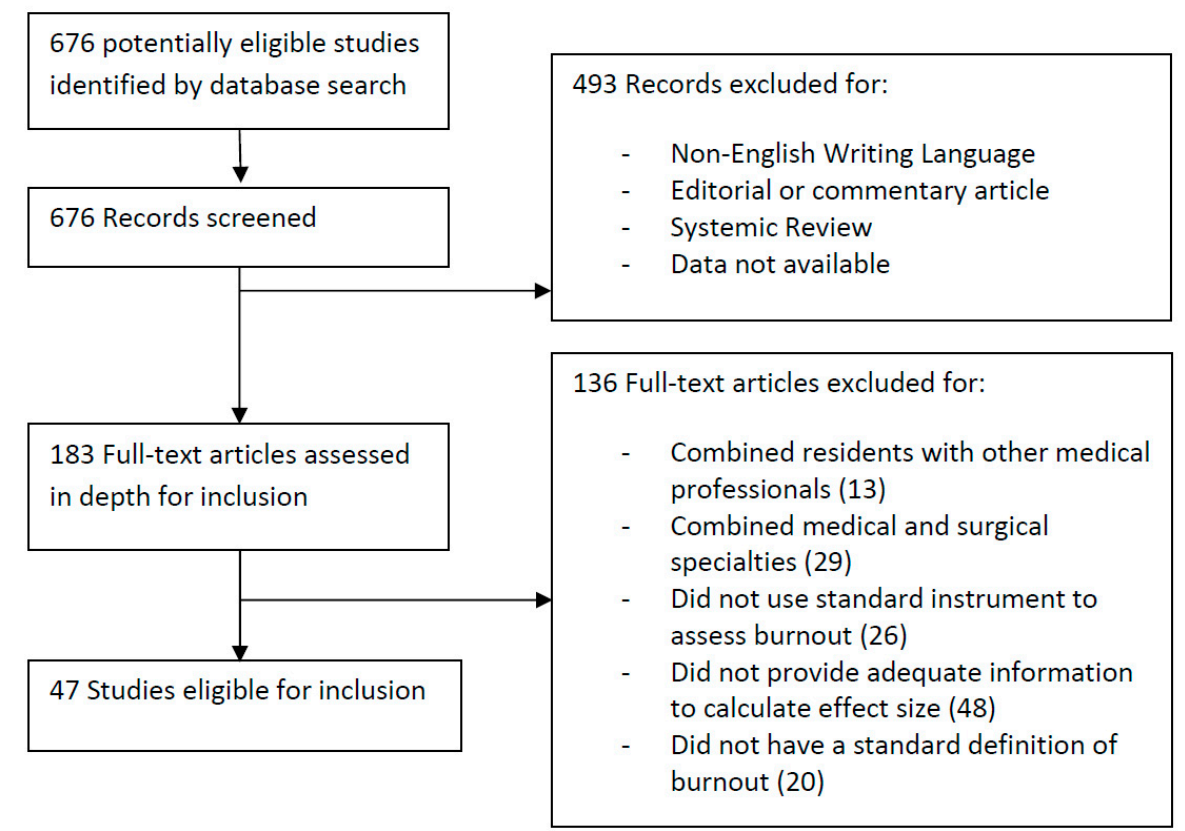

Figure 1. Study selection process.

Table 1 summarizes the characteristics of the included studies. For this study, thirty-seven (37) $(78.72 \%)$ studies were from North and South America (Canada, USA, Brazil) [32-66], three (3) studies (6.38\%) were from Europe (France, Spain) [67-69], five (5) studies (10.63\%) were from Asia (Pakistan, Saudi Arabia, Turkey) [70-74], as well as one (1) study (2.13\%) each from Africa (Egypt) [75] and Australia [76]. The mean age of individual participants varied from 25.9 to 32.0 years, with the proportion of male residents ranging from $10 \%$ to $88 \%$.

\subsection{Aggregate Prevalence of Burnout}

A total of 22,778 individual participants were included in the meta-analysis to calculate the aggregate prevalence of burnout (Figure 2). The aggregate prevalence of burnout was 51.0\% (95\% CI: 45.0-57.0\%, $\left.\mathrm{I}^{2}=96.96 \%\right)$. Publication bias was not present as confirmed by the Egger's regression test (intercept $=-0.051, p=0.95)$. Meta-regression found that the mean age of residents $(\beta=0.34,95 \% \mathrm{CI}$ : $0.28-0.40, p<0.001)$ and proportion of males $(\beta=0.4,95 \% \mathrm{CI}=0.1-0.69, p=0.009)$ were significant moderators. The publication year of study $(\beta=-0.0036,95 \% \mathrm{CI}:-0.014-0.0071, p=0.51)$ and response rate of residents $(\beta=-0.086,95 \% \mathrm{CI}:-0.24-0.072, p=0.28)$ were not statistically significant moderators.

There were $18,759(82.36 \%)$ residents in surgical residencies including general surgery, neurosurgery, obstetrics and gynecology, ophthalmology, orthopedics, and otolaryngology. The prevalence rate of burnout in surgical residents was 53.27\% (95\% CI: 46.27-60.15\%) (Figure 3). There were 4019 (17.64\%) residents in medical residencies including anesthesia, dermatology, emergency medicine, family medicine, internal medicine, neurology, oncology, pediatrics, psychiatry, and radiology. The prevalence rate of burnout in medical residents was 50.13\% (95\% CI: 42.12-58.13\%) (Figure 3). Although the prevalence of burnout was higher among surgical residents, the difference was not statistically significant $(\mathrm{Q}=0.92, p=0.34)$. 
Table 1. Characteristics of included studies.

\begin{tabular}{|c|c|c|c|c|c|c|c|c|c|c|}
\hline \multirow[b]{2}{*}{ Study } & \multicolumn{4}{|c|}{ Study Demographics } & \multicolumn{5}{|l|}{ Study Results } & \multirow[b]{2}{*}{$\begin{array}{l}\text { MBI/Abbrev. } \\
\text { MBI }\end{array}$} \\
\hline & Country & Region & Mean Age & $\begin{array}{l}\text { Proportion } \\
\text { of Males }\end{array}$ & Specialty & $\begin{array}{l}\text { Medical/ } \\
\text { Surgical }\end{array}$ & $\begin{array}{l}\text { Response } \\
\text { Rate }\end{array}$ & $\begin{array}{l}\text { Sample } \\
\text { Size }\end{array}$ & $\begin{array}{l}\text { Number of } \\
\text { Residents Who } \\
\text { Reported Burnout }\end{array}$ & \\
\hline Garza et al., 2004 [45] & USA & N. America & NR & 0.29 & $\begin{array}{l}\text { Obstetrics and } \\
\text { Gynecology }\end{array}$ & Surgical & $37 \%$ & 136 & 52 & MBI \\
\hline Gelfand et al., 2004 [46] & USA & N. America & NR & NR & General Surgery & Surgical & $69 \%$ & 37 & 21 & MBI \\
\hline Martini et al., 2004a [44] & USA & N. America & NR & NR & $\begin{array}{l}\text { Obstetrics and } \\
\text { Gynecology }\end{array}$ & Surgical & $35 \%$ & 36 & 12 & MBI \\
\hline Martini et al., 2004b [44] & USA & N. America & NR & NR & Internal Medicine & Medical & $35 \%$ & 114 & 24 & MBI \\
\hline Martini et al., 2004c [44] & USA & N. America & NR & NR & Neurology & Medical & $35 \%$ & 16 & 8 & MBI \\
\hline Martini et al., 2004d [44] & USA & N. America & NR & NR & Ophthalmology & Surgical & $35 \%$ & 21 & 5 & MBI \\
\hline Martini et al., 2004e [44] & USA & N. America & NR & NR & Dermatology & Medical & $35 \%$ & 10 & 6 & MBI \\
\hline Martini et al., 2004f [44] & USA & N. America & NR & NR & General Surgery & Surgical & $35 \%$ & 59 & 25 & MBI \\
\hline Martini et al., 2004g [44] & USA & N. America & NR & NR & Psychiatry & Medical & $35 \%$ & 29 & 15 & MBI \\
\hline Martini et al., 2004h [44] & USA & N. America & NR & NR & Family Medicine & Medical & $35 \%$ & 36 & 15 & MBI \\
\hline Goitein et al., 2005 [43] & USA & N. America & NR & 0.47 & Internal Medicine & Medical & $73 \%$ & 118 & 80 & MBI \\
\hline Gopal et al., 2005 [42] & USA & N. America & 29.9 & 0.58 & Internal Medicine & Medical & $87 \%$ & 121 & 74 & MBI \\
\hline Castelo-Branco et al., 2007 [68] & Spain & Europe & 27.0 & 0.14 & $\begin{array}{l}\text { Obstetrics and } \\
\text { Gynecology }\end{array}$ & Surgical & $67 \%$ & 109 & 63 & MBI \\
\hline Landrigan et al., 2008 [41] & USA & N. America & 30.2 & 0.29 & Pediatrics & Medical & $59 \%$ & 220 & 141 & MBI \\
\hline Ghetti et al., 2009 [40] & USA & N. America & 28.0 & NR & $\begin{array}{l}\text { Obstetrics and } \\
\text { Gynecology }\end{array}$ & Surgical & $47 \%$ & 17 & 13 & MBI \\
\hline Hill and Smith, 2009 [48] & USA & N. America & NR & NR & Otolaryngology & Surgical & $76 \%$ & 22 & 7 & MBI \\
\hline Sargent et al., 2009 [39] & USA & N. America & NR & 0.88 & Orthopedics & Surgical & NR & 384 & 215 & MBI \\
\hline Blanchard et al., 2010 [67] & France & Europe & 28.0 & 0.40 & Oncology & Medical & $60 \%$ & 204 & 89 & MBI \\
\hline Campbell et al., 2010 [47] & USA & N. America & 30.0 & 0.51 & Internal Medicine & Medical & $48 \%$ & 86 & 58 & MBI \\
\hline Ripp et al., 2010 [38] & USA & N. America & NR & 0.50 & Internal Medicine & Medical & $94 \%$ & 145 & 50 & MBI \\
\hline Billings et al., 2011 [37] & USA & N. America & NR & NR & Internal Medicine & Medical & $43 \%$ & 284 & 128 & Abbrev. MBI \\
\hline Ripp et al., 2011 [20] & USA & N. America & NR & 0.48 & Internal Medicine & Surgical & $73 \%$ & 191 & 154 & MBI \\
\hline West et al., 2011 [36] & USA & N. America & NR & 0.57 & General Surgery & Surgical & $77 \%$ & 16,394 & 8343 & Abbrev. MBI \\
\hline Doolittle et al., 2013 [35] & USA & N. America & 30.0 & 0.50 & Internal Medicine & Medical & $63 \%$ & 108 & 94 & MBI \\
\hline
\end{tabular}


Table 1. Cont.

\begin{tabular}{|c|c|c|c|c|c|c|c|c|c|c|}
\hline \multirow[b]{2}{*}{ Study } & \multicolumn{4}{|c|}{ Study Demographics } & \multicolumn{5}{|l|}{ Study Results } & \multirow[b]{2}{*}{$\begin{array}{l}\text { MBI/Abbrev. } \\
\text { MBI }\end{array}$} \\
\hline & Country & Region & Mean Age & $\begin{array}{l}\text { Proportion } \\
\text { of Males }\end{array}$ & Specialty & $\begin{array}{l}\text { Medical/ } \\
\text { Surgical }\end{array}$ & $\begin{array}{l}\text { Response } \\
\text { Rate }\end{array}$ & $\begin{array}{l}\text { Sample } \\
\text { Size }\end{array}$ & $\begin{array}{l}\text { Number of } \\
\text { Residents Who } \\
\text { Reported Burnout }\end{array}$ & \\
\hline Lebensohn et al., 2013 [34] & USA & N. America & 29.0 & 0.40 & Family Medicine & Medical & $77 \%$ & 167 & 23 & MBI \\
\hline Shams and El-Masry, 2013 [75] & Egypt & Africa & NR & NR & Anesthesia & Medical & $73 \%$ & 30 & 21 & MBI \\
\hline Aksoy et al., 2014a [70] & Turkey & Asia & 25.9 & 0.45 & Pediatrics & Medical & $66 \%$ & 22 & 6 & MBI \\
\hline Aksoy et al., 2014b [70] & Turkey & Asia & 26.6 & 0.48 & Internal Medicine & Medical & $66 \%$ & 33 & 11 & MBI \\
\hline Arora et al., 2014 [76] & Australia & Oceania & NR & 0.88 & Orthopedics & Surgical & $22 \%$ & 51 & 27 & MBI \\
\hline Pantaleoni et al., 2014 [33] & USA & N. America & NR & NR & Pediatrics & Medical & $100 \%$ & 54 & 9 & MBI \\
\hline Rutherford and Oda, 2014 [65] & Canada & N. America & 29.5 & 0.10 & Family Medicine & Medical & $4 \%$ & 10 & 7 & MBI \\
\hline Aldrees et al., 2015 [71] & $\begin{array}{l}\text { Saudi } \\
\text { Arabia }\end{array}$ & Asia & 29.0 & 0.67 & Otolaryngology & Surgical & $69 \%$ & 85 & 38 & MBI \\
\hline Lu et al., 2015 [32] & USA & N. America & NR & NR & $\begin{array}{l}\text { Emergency } \\
\text { Medicine }\end{array}$ & Medical & $50 \%$ & 27 & 17 & MBI \\
\hline Shapiro et al., 2015 [58] & USA & N. America & NR & 0.51 & Internal Medicine & Medical & $77 \%$ & 95 & 43 & MBI \\
\hline Ripp et al., 2015a [63] & USA & N. America & NR & 0.44 & Internal Medicine & Medical & $62 \%$ & 108 & 91 & MBI \\
\hline Cubero et al., 2016 [77] & Brazil & S. America & 28.4 & 0.54 & Oncology & Medical & $31 \%$ & 54 & 15 & MBI \\
\hline Lin et al., 2016 [62] & USA & N. America & 30.8 & 0.58 & General Surgery & Surgical & $63 \%$ & 73 & 60 & MBI \\
\hline Spataro et al., 2016 [61] & USA & N. America & 29.9 & 0.51 & Internal Medicine & Medical & $69 \%$ & 198 & 45 & MBI \\
\hline Kwah et al., 2016 [73] & Pakistan & Asia & NR & NR & Internal Medicine & Medical & $59 \%$ & 32 & 24 & MBI \\
\hline Ripp et al., 2016 [60] & USA & N. America & NR & NR & Internal Medicine & Medical & $76 \%$ & 39 & 17 & MBI \\
\hline Winkel et al., 2016 [59] & USA & N. America & NR & NR & $\begin{array}{l}\text { Obstetrics and } \\
\text { Gynecology }\end{array}$ & Surgical & $64 \%$ & 42 & 28 & MBI \\
\hline Zubairi and Noordin, 2016a [72] & Pakistan & Asia & NR & 0.54 & General Surgery & Surgical & $54 \%$ & 24 & 19 & MBI \\
\hline Zubairi and Noordin, 2016b [72] & Pakistan & Asia & NR & 0.54 & Internal Medicine & Medical & $54 \%$ & 32 & 25 & MBI \\
\hline Zubairi and Noordin, 2016c [72] & Pakistan & Asia & NR & 0.54 & Pediatrics & Medical & $54 \%$ & 11 & 5 & MBI \\
\hline Zubairi and Noordin, 2016d [72] & Pakistan & Asia & NR & 0.54 & Radiology & Medical & $54 \%$ & 5 & 5 & MBI \\
\hline Zubairi and Noordin, 2016e [72] & Pakistan & Asia & NR & 0.54 & Anesthesia & Medical & $54 \%$ & 10 & 7 & MBI \\
\hline
\end{tabular}


Table 1. Cont.

\begin{tabular}{|c|c|c|c|c|c|c|c|c|c|c|}
\hline \multirow[b]{2}{*}{ Study } & \multicolumn{4}{|c|}{ Study Demographics } & \multicolumn{5}{|l|}{ Study Results } & \multirow[b]{2}{*}{$\begin{array}{l}\text { MBI/Abbrev. } \\
\text { MBI }\end{array}$} \\
\hline & Country & Region & Mean Age & $\begin{array}{l}\text { Proportion } \\
\text { of Males }\end{array}$ & Specialty & $\begin{array}{l}\text { Medical/ } \\
\text { Surgical }\end{array}$ & $\begin{array}{l}\text { Response } \\
\text { Rate }\end{array}$ & $\begin{array}{l}\text { Sample } \\
\text { Size }\end{array}$ & $\begin{array}{l}\text { Number of } \\
\text { Residents Who } \\
\text { Reported Burnout }\end{array}$ & \\
\hline Attenello et al., 2017 [66] & USA & N. America & 30.9 & 0.78 & Neurosurgery & Surgical & $21 \%$ & 346 & 232 & Abbrev. MBI \\
\hline Baer et al., 2017 [57] & USA & N. America & 29.4 & 0.21 & Pediatrics & Medical & $53 \%$ & 258 & 101 & Abbrev. MBI \\
\hline Braun et al. 2017 [64] & USA & N. America & 28.6 & 0.79 & Internal Medicine & Medical & $30 \%$ & 38 & 19 & MBI \\
\hline Busis et al., 2017 [54] & USA & N. America & 32.0 & 0.51 & Neurology & Medical & $38 \%$ & 212 & 156 & MBI \\
\hline Chaukos et al., 2017 [56] & USA & N. America & 28.3 & 0.40 & Psychiatry & Medical & $80 \%$ & 68 & 19 & MBI \\
\hline Guenette and Smith, 2017 [55] & USA & N. America & NR & 0.63 & Radiology & Medical & $20 \%$ & 94 & 35 & MBI \\
\hline Ramey et al., 2017 [53] & USA & N. America & NR & 0.69 & Oncology & Medical & $32 \%$ & 232 & 86 & MBI \\
\hline Shakir et al., 2017 [52] & USA & N. America & NR & 0.80 & Neurosurgery & Surgical & $21 \%$ & 255 & 93 & Abbrev. MBI \\
\hline Slavin et al., 2017 [51] & USA & N. America & NR & NR & Pediatrics & Medical & NR & 18 & 14 & MBI \\
\hline Waheed et al., 2017 [74] & Pakistan & Asia & 27.5 & NR & $\begin{array}{l}\text { Obstetrics and } \\
\text { Gynecology }\end{array}$ & Surgical & NR & 102 & 54 & MBI \\
\hline Yrondi et al., 2017a [69] & France & Europe & 28.8 & 0.55 & Anesthesia & Medical & NR & 123 & 11 & MBI \\
\hline Yrondi et al., 2017b [69] & France & Europe & 27.7 & 0.33 & Psychiatry & Medical & NR & 148 & 20 & MBI \\
\hline Lebares et al., 2018 [50] & USA & N. America & NR & 0.49 & General Surgery & Surgical & $10 \%$ & 566 & 322 & MBI \\
\hline Shoimer et al., 2018 [49] & Canada & N. America & NR & NR & Dermatology & Medical & $59 \%$ & 96 & 49 & MBI \\
\hline
\end{tabular}

Notes: Papers which analyzed more than one cohort of residencies (for example, residents from different batches or specialties) are given specific letters of the alphabet (a, $\mathrm{b}$, $\mathrm{c}$, etc.) in their suffixes. Abbreviations: MBI = Maslach Burnout Inventory, Abbrev. MBI = Abbreviated version of MBI, N. America = North America, $\mathrm{S}$. America $=$ South America, NR = Not reported. 

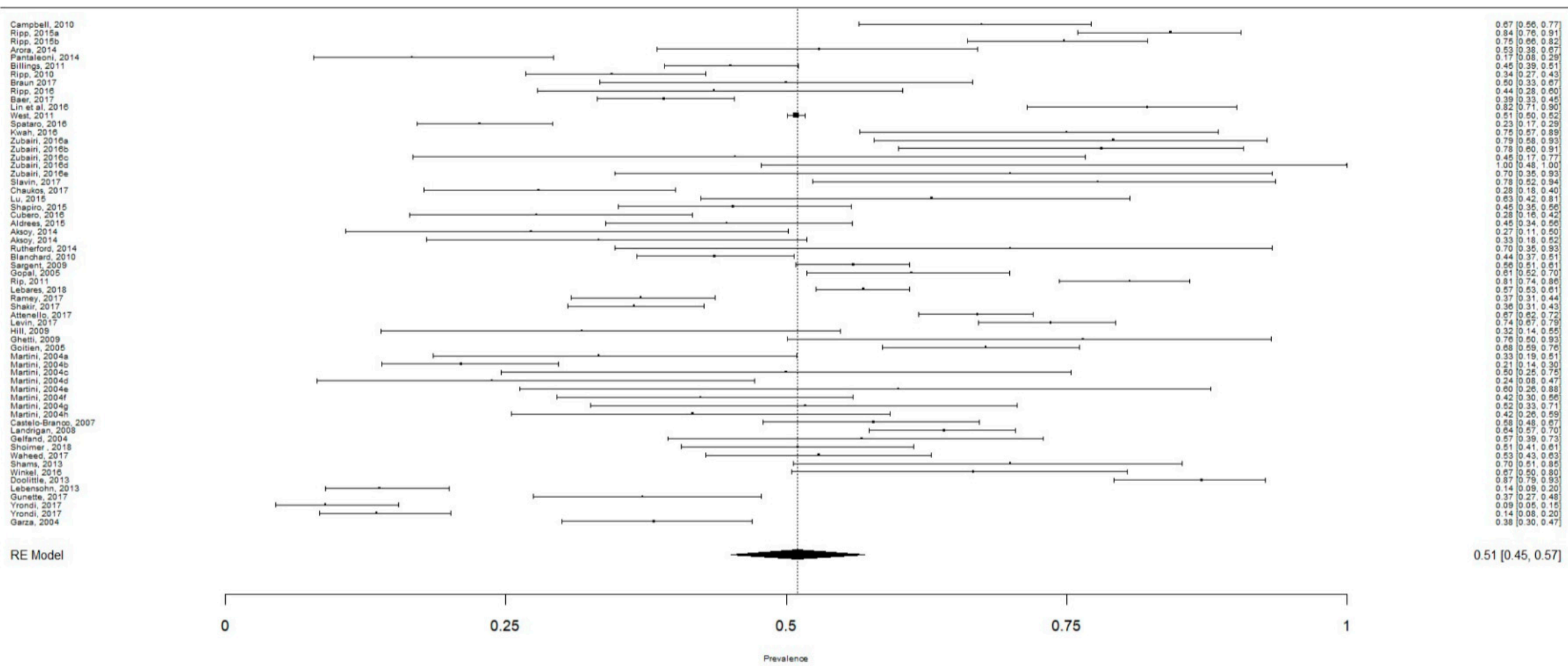

Figure 2. The aggregate prevalence of burnout in all residents 


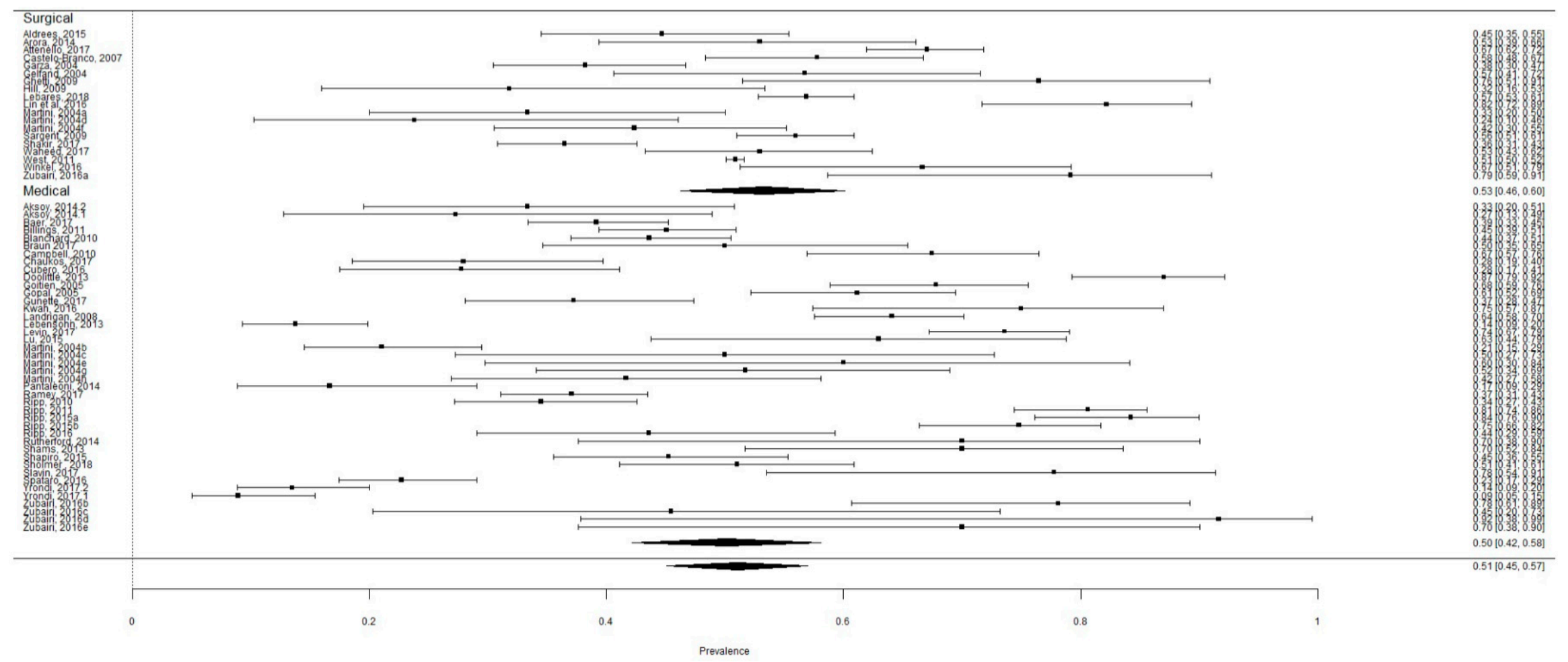

Figure 3. The aggregate prevalence of burnout in medical and surgical residents. 


\subsection{Subgroup Analysis}

In the subgroup analysis by specialty (Table 2), radiology (77.16\%, 95\% CI: 5.99-99.45), neurology (71.93\%, 95\% CI: 65.78-77.39), and general surgery (58.39\%, 95\% CI: 45.72-70.04) were the top three specialties with the highest prevalence rates of burnout. In addition, more than $50 \%$ of residents experienced burnout in internal medicine (57.11\%, 95\% CI: 45.11-68.33), orthopedics ( $55.63 \%$, 95\% CI: 50.93-60.28), dermatology (51.89\%, 95\% CI: 42.42-61.21), obstetrics and gynecology (52.84\%, 95\% CI: 41.77-63.63), and neurosurgery (52.02\%, 95\% CI: 31.02-72.33). In contrast, psychiatry $(42.05 \%, 95 \%$ CI: $33.09-51.58)$, oncology (38.36\%, 95\% CI: 32.69-44.37), and family medicine (35.97\%, 95\% CI: $13.89-66.18)$ had the lowest prevalence rates of burnout. However, there was no statistically significant difference in prevalence rates among various specialties $(Q=13.9, p=0.53)$. In the subgroup analysis by geographical region (Table 2), several European countries had the prevalence of burnout 27.72\% (95\% CI: 17.4-41.11). Several Asian countries had the highest prevalence of burnout 57.18\% (95\% CI: 45.8-67.85). However, the difference in prevalence rates among various continents was not statistically significant $(Q=9.43$, $p=0.093)$.

Table 2. Prevalence of burnout in residents by subgroup analysis.

\begin{tabular}{|c|c|c|c|}
\hline Medical Specialty/Region & $\begin{array}{c}\text { Number of Residents } \\
\text { (pct.) }\end{array}$ & $\begin{array}{c}\text { Burnout Prevalence pct. } \\
\text { and } 95 \% \text { CI }\end{array}$ & $\mathrm{I}^{2}$ \\
\hline All residents & $22,778(100 \%)$ & $51.0 \%(45.0-57.0)$ & $97.0 \%$ \\
\hline \multicolumn{4}{|c|}{ Surgical vs. medical: $p$ (subgroup difference) $=0.337$} \\
\hline Surgical residents & $18,759(82.36 \%)$ & $53.27 \%(46.27-60.15)$ & $94.8 \%$ \\
\hline Medical residents & $4019(17.64 \%)$ & $50.13 \%(42.12-58.13)$ & $95.0 \%$ \\
\hline \multicolumn{4}{|c|}{ * Specialty: $p$ (subgroup difference) $=0.533$} \\
\hline Radiology & $99(0.43 \%)$ & $77.16 \%(5.99-99.45)$ & $77.8 \%$ \\
\hline Neurology & $228(1 \%)$ & $71.93 \%(65.78-77.39)$ & $0 \%$ \\
\hline General Surgery & $17,153(75.31 \%)$ & $58.39 \%(45.72-70.04)$ & $96.0 \%$ \\
\hline Internal Medicine & $1865(8.19 \%)$ & $57.11 \%(45.11-68.33)$ & $95.3 \%$ \\
\hline Orthopedics & $435(1.91 \%)$ & $55.63 \%(50.93-60.28)$ & $96.3 \%$ \\
\hline Dermatology & $106(0.47 \%)$ & $51.89 \%(42.42-61.21)$ & $0 \%$ \\
\hline Obstetrics and Gynecology & $442(1.94 \%)$ & $52.84 \%$ (41.77-63.63) & $78.0 \%$ \\
\hline Neurosurgery & $601(2.63 \%)$ & $52.02 \%(31.02-72.33)$ & $96.3 \%$ \\
\hline Pediatrics & $583(2.6 \%)$ & $43.74 \%(26.70-62.39)$ & $92.3 \%$ \\
\hline Anesthesia & $163(0.71 \%)$ & 43.71\% (11.15-82.29) & $92.3 \%$ \\
\hline Otolaryngology & $107(0.47 \%)$ & $42.06 \%(33.09-51.58)$ & $0.0 \%$ \\
\hline Psychiatry & $245(1.08 \%)$ & $42.05 \%(33.09-51.58)$ & $89.6 \%$ \\
\hline Oncology & $490(2.15 \%)$ & $38.36 \%(32.69-44.37)$ & $27.6 \%$ \\
\hline Family Medicine & $213(0.94 \%)$ & $35.97 \%(13.89-66.18)$ & $88.4 \%$ \\
\hline \multicolumn{4}{|l|}{${ }^{+}$Region: $p$ (subgroup difference) $=0.093$} \\
\hline $\begin{array}{l}\text { Several Asian countries (Pakistan, } \\
\text { Saudi Arabia, and Turkey) }\end{array}$ & $356(1.56 \%)$ & $57.18 \%(45.80-67.85)$ & $80.9 \%$ \\
\hline $\begin{array}{l}\text { Several European countries } \\
\text { (France, Spain) }\end{array}$ & $584(2.56 \%)$ & $27.72 \%(17.40-41.11)$ & $96.4 \%$ \\
\hline North America & $21,757(95.52 \%)$ & $51.64 \%(46.96-56.28)$ & $97.1 \%$ \\
\hline
\end{tabular}




\section{Discussion}

This meta-analysis compared burnout prevalence rates by medical specialty, and summarized data on the overall prevalence of burnout in residents. There were several important findings. First, the global prevalence of burnout among residents was considerably high-over $50 \%$. Second, the prevalence of burnout was comparable between medical and surgical residents. Third, more than half of the residents from eight specialties (radiology, neurology, general surgery, internal medicine, orthopedics, dermatology, obstetrics and gynecology, and neurosurgery) reported burnout, although there was no statistically significant difference in prevalence rates among various specialties. Older age and male gender were associated with higher prevalence of burnout. Interestingly, the year of publication was not a significant moderator, suggesting that the prevalence of burnout does not change with time.

\subsection{Potential Reasons for High Prevalence of Burnout in Some Medical and Surgical Specialities}

We found that more than half of medical and surgical residents experienced burnout. Symptoms of burnout can originate from many causes, such as bureaucratic requirements [78], continually changing work environments [17], micro-management by the administration, poor clinical supervision, sensationalist media reports of medical errors [79], limited healthcare resources [17], litigious environments [80], and poor work-life balance [81]. The prevalence of burnout among psychiatry residents was less than $50 \%$. This finding is not surprising because psychiatry residency offers training in different modalities of psychotherapy, including cognitive behavior therapy, interpersonal therapy, supportive psychotherapy, and problem-solving psychotherapy. Perhaps, psychiatry residents can apply psychotherapeutic techniques to reduce or overcome symptoms of burnout and negative emotion. In contrast, we found that radiology residents had the highest prevalence rate of burnout. The radiology training lacks direct interaction with patients and focuses on the technical aspects of various imaging modalities and interpretation of images to establish diagnoses. As a result, the radiology residents may lack clinical and psychotherapeutic skills to handle burnout and negative emotion. Furthermore, the radiology residents work in academic institutions, where they are often worried about errors in diagnosis and criticism by other specialties. The insecurity may increase further with the advent of artificial intelligence in the interpretation of images, which could impact a sense of potential job displacement [82].

\subsection{Extension of Burnout from Medical Schools into Residencies}

The present study helps illuminate some of the factors that were not apparent in previous studies of burnout among medical students and trainees. A recent meta-analysis reported that burnout ranged from $7 \%$ to $75 \%$ among medical students [83]. However, this study did not provide an aggregate prevalence of burnout or examine possible geographical differences. Nevertheless, burnout in residency could originate from burnout in medical school, possibly due to a lack of awareness and intervention by universities and health authorities. Burnout and depression are interrelated [84]. Medical students with burnout are more likely to experience depression, which is associated with work-related disability and loss of productivity after graduation [85]. Puthran et al. (2016) [31] performed a meta-analysis and found that the global prevalence of depression among medical students was $28 \%$. Graduate medical program (e.g., the M.D. system in North America) and receiving medical education in Middle Eastern countries were factors contributing to depression among medical students. Similarly, older age was a significant moderator contributing to burnout among residents. Lastly, residents are finding themselves working in roles for which they were not trained in the medical schools, including hospital accreditation processes, clinical audits, and administrative and teaching roles, all of which could contribute to burnout in residency. 


\subsection{Comparison with Other Healthcare Professions}

Similar to medical students, other healthcare professionals also suffer from burnout. Monsalve-Reyes et al. (2018) reported a relatively lower (31\%) prevalence of burnout among 1110 primary care nurses [86]. In our meta-analysis, family medicine residents had the lowest aggregate prevalence of burnout among all residents, which is different from a study conducted in the USA [87]. Similar to family medicine residents, primary care nurses manage stable patients with chronic diseases in their homes and communities, which allows them to form stronger bonds with the patients and helps prevent burnout [86]. In contrast, residents from hospital-based specialties often manage unstable patients with acute diseases with various complications, which may contribute to a higher prevalence of burnout. Furthermore, residents who receive hospital-based training are more likely to face litigations, compared with residents in primary care [17].

We found high between-study heterogeneity $(>90 \%)$ among neurosurgery, orthopedics, internal medicine, general surgery, anesthesia, and pediatrics. This might be due to different countries and their residency structures, assessment methods, medico-legal practices, number of stay-in calls, pay scales, workplace conditions, job security, and employment opportunities.

\subsection{Differences in Residency Burnout between the East and West}

Some of these observations are substantiated by our subgroup analyses that showed differences in the prevalence rates of burnout among different continents, although such differences were not statistically significant. The contributing factors to high prevalence of burnout among residents in some Asian countries could include long working hours, high educational pressures, lack of autonomy, high levels of work-home intrusion, and professional uncertainty [88,89]. These stressors are prevalent in some Asian countries. Furthermore, there is no advocacy to safeguard working conditions for residents in some Asian countries. In contrast, the European Working Time Directive stated a maximum of 48 working hours per week, and residency training programs in European countries demonstrated good compliance [90]. Interestingly, the prevalence of burnout in North America was higher than in several European countries. That might be explained by differences in work hours and compliance rates. The Accreditation Council for Graduate Medical Education of the USA allows an 80-h work limit per week for residents [91], and the compliance rates of residency programs were low [92].

\subsection{Future Research}

We found that older age of residents was significantly associated with higher prevalence of burnout. There are several postulations. First, older residents might enter residency late due to difficulty in choosing the specialty. Second, older residents might find it difficult to cope with the training demands and postgraduate examinations as compared with younger residents. Third, older residents are more likely to be married and could be coping with family commitments as well as the need to sit for examinations, conduct research, and perform administrative duties [93]. This observation might explain why male gender, especially married male residents, was significantly associated with higher prevalence of burnout. This is an important finding since men are less likely to admit psychological suffering and seek help as compared with women [94]. 
Future research should include a prospective study to evaluate the psychological, occupational, training, and sociodemographic factors that may influence the development of burnout syndrome among residents. None of the studies included in this meta-analysis assessed associations between burnout and employment rates of residents. Future research should examine this and other long-term effects of burnout. Residents often deal with burnout by avoidance and denial [95]. Neglected burnout often leads to alcohol and substance misuse, anxiety, depression, discontinuation of residency, fatigue, impaired interpersonal and marital relationship, and insomnia [17]. It is unclear why mental health has been neglected as part of the occupational health agenda for medical and surgical residents. It may be that training administrators are unaware of burnout, or that they believe current practices help strengthen medical practitioners for real-world working conditions.

\subsection{Policy Implications}

Our findings have important policy implications. Policymakers should prepare health systems for the proper management of burnout in residents, including evidence-based psychological interventions. Health authorities should offer early detection and prevention programs to tackle burnout in residents. Specialties with very high burnout rates $(>50 \%)$ should consider structural and organizational changes in the training program to improve the training environment, competency of trainers, opportunities for career development, and satisfaction of residents. Residency programs in some Asian countries, and elsewhere, should improve work-life balance and set limits on working hours.

\subsection{Strengths and Limitations}

Strengths of this meta-analysis include the use of a comprehensive search strategy, the involvement of at least two independent researchers throughout the research process. Due to the robust search strategy, the sample size of our meta-analysis $(n=22,778)$ was almost five times higher than a recent meta-analysis on burnout of medical residents $(n=4664)$ [96]. This meta-analysis included studies which used the Maslach Burnout Inventory (MBI). The lack of publication bias suggests that we were unlikely to miss studies that could have altered the results of our meta-analysis. Our approach avoided different ways to define and measure burnout, which is the main limitation of current burnout research [97]. Unless burnout can be measured by neuroimaging or other biological methods as in some psychiatric symptoms $[98,99]$, the MBI remains the most established way to measure burnout when this meta-analysis was conducted.

This meta-analysis has several limitations. First, all included studies were observational which could lead to inherent bias because of unmeasured confounders, including workloads and resources for each residency program, genetic risk for depression, past psychiatric illness, and substance abuse. Similarly, we were unable to extract some correlates of burnout (e.g., weekly working hours, marital status, financial status, job satisfaction) as the underlying data sets did not provide such information. Second, although mean age and proportion of males were moderators for meta-regression, it is important to note that 38 out of 60 studies $(63.33 \%)$ and 21 out of 60 studies (35\%) did not report mean age and proportion of gender, respectively. Furthermore, the results of meta-regressions suggest observational associations but not causations due to ecological fallacy [100]. Third, this study was aimed at evaluating the prevalence of burnout among residents using the largest number of studies possible, across all specialties, but the distribution of the number of residents per specialty was uneven. This meta-analysis included 22,778 residents, of whom 17,153 belonged to surgery, with the next highest group belonging to internal medicine at 4019 , whereas other specialties had much lower residents with psychiatry at 245 , neurology at 228 , family medicine at 213 , and radiology at 99 . This is one of the key limitations of this meta-analysis as some of the specialties were under-represented. Fourth, we were not able to compare the prevalence of individual components of burnout (e.g., low personal achievement), due to differences in how studies assessed burnout symptoms. Lastly, many of the studies were conducted in the USA, with fewer conducted in developing countries (e.g., Vietnam) and emerging economies (e.g., China, India) where residents encounter heavy workloads, low wages, and 
lack of respect from patients [101,102]. Of particular note, there is a paucity of research in Europe, Asia, Australia, and Africa and on some specialties including emergency medicine and ophthalmology. As a result, the subgroup analysis based on continents should be interpreted with caution.

\section{Conclusions}

The results of this meta-analysis suggest a high prevalence of burnout in residents-over $50 \%$. Our findings showed that burnout is prevalent in all specialties, but that some specialties have much higher rates than others. Results also demonstrated that age, sex, and geographic location could all influence burnout rates. Burnout has negative impacts on job satisfaction, the health of the residents, and the delivery of clinical services to patients. More studies are required to identify plausible causal pathways between residency training and burnout. Policymakers and health authorities should use available evidence to help immediately improve detection, overall management, and prevention of burnout in residents. Our findings suggest the urgent need for structural and organizational changes for residency programs, specific to local training environment and other demographic factors, to reduce the prevalence of burnout among residents.

Author Contributions: Conceptualization, Z.X.L., K.A.Y., and R.C.H.; methodology, Z.X.L., K.A.Y., W.W.T., and R.C.H.; software, Z.X.L., K.A.Y., W.W.T., and R.C.H.; validation, W.W.T., C.S.H., A.G., and B.L.; formal analysis, Z.X.L., K.A.Y., W.W.T., and R.C.H.; investigation, Z.X.L., K.A.Y., and R.C.H.; resources, W.W.T. and R.C.H.; data curation, Z.X.L. and K.A.Y.; writing-original draft preparation, Z.X.L., K.A.Y., and R.C.H.; writing一review and editing, V.K.S., R.S.M., G.K.L., A.G., B.L., C.C.S.F.L., B.X.T., L.H.N., and C.S.H.; visualization, Z.X.L., K.A.Y., W.W.T., and R.C.H.; supervision, V.K.S., G.K.L., R.S.M., A.G., B.L., and B.X.T.; project administration, Z.X.L., K.A.Y., and R.C.H.

Funding: This research received no external funding.

Conflicts of Interest: The authors declare no conflict of interest. 


\section{Appendix A}

\begin{tabular}{|c|c|c|c|c|c|c|c|c|c|c|c|c|c|c|}
\hline Criteria/Name & 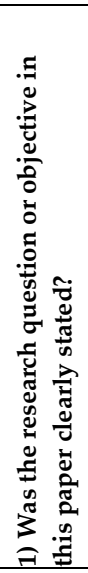 & 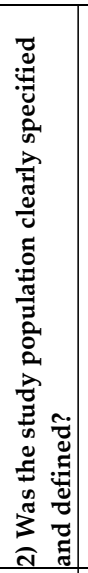 & 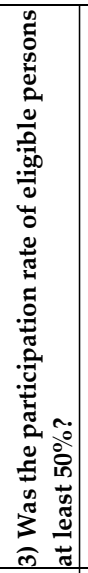 & 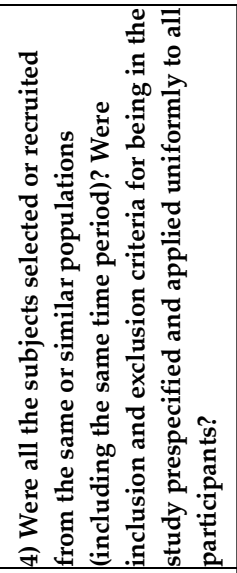 & 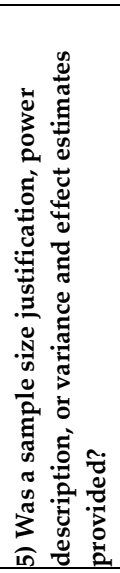 & 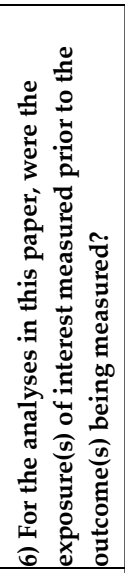 & 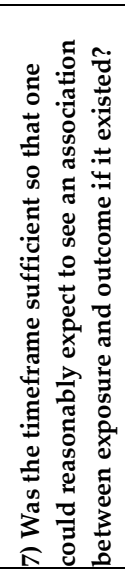 & 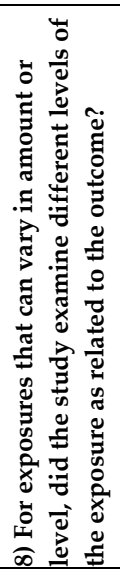 & 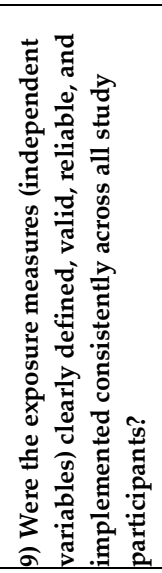 & 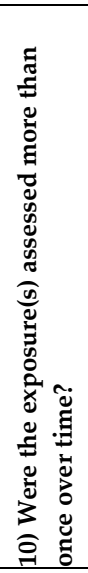 & 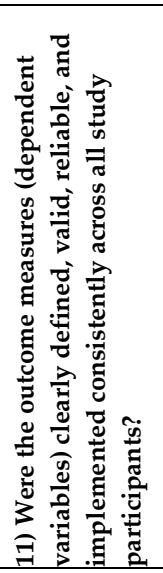 & 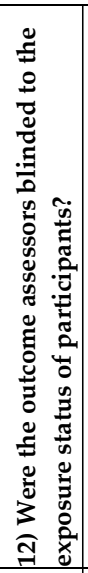 & 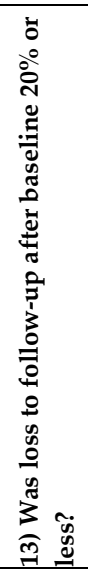 & 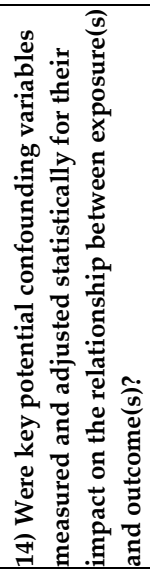 \\
\hline Garza et al., 2004 [45] & $\mathbf{Y}$ & $\mathrm{Y}$ & $\mathbf{N}$ & $\mathrm{Y}$ & $\mathbf{N}$ & $\mathbf{N}$ & $\mathbf{N}$ & NA & $Y$ & NA & $\mathrm{Y}$ & $\mathbf{N}$ & NA & $\mathbf{N}$ \\
\hline Gelfand et al., 2004 [46] & $\mathbf{Y}$ & $\mathrm{Y}$ & $\mathrm{Y}$ & $\mathrm{Y}$ & $\mathbf{N}$ & $\mathbf{N}$ & $\mathbf{N}$ & NA & $\mathbf{Y}$ & NA & $\mathbf{Y}$ & $\mathbf{N}$ & NA & $\mathbf{N}$ \\
\hline Martini et al., 2004a [44] & $\mathrm{Y}$ & $\mathrm{Y}$ & $\mathbf{N}$ & $\mathrm{Y}$ & $\mathbf{N}$ & $\mathbf{N}$ & $\mathbf{N}$ & NA & $\mathrm{Y}$ & NA & $\mathrm{Y}$ & $\mathbf{N}$ & NA & $\mathbf{N}$ \\
\hline Martini et al., 2004b [44] & $\mathrm{Y}$ & $\mathrm{Y}$ & $\mathbf{N}$ & $\mathrm{Y}$ & $\mathrm{N}$ & $\mathbf{N}$ & $\mathbf{N}$ & NA & $\mathrm{Y}$ & NA & $\mathrm{Y}$ & $\mathbf{N}$ & NA & $\mathbf{N}$ \\
\hline Martini et al., 2004c [44] & $\mathbf{Y}$ & $\mathbf{Y}$ & $\mathbf{N}$ & $\mathbf{Y}$ & $\mathbf{N}$ & $\mathbf{N}$ & $\mathbf{N}$ & NA & $\mathbf{Y}$ & NA & $\mathrm{Y}$ & $\mathbf{N}$ & NA & $\mathbf{N}$ \\
\hline Martini et al., 2004d [44] & $\mathbf{Y}$ & $\mathrm{Y}$ & $\mathbf{N}$ & $\mathbf{Y}$ & $\mathbf{N}$ & $\mathbf{N}$ & $\mathbf{N}$ & NA & $\mathrm{Y}$ & NA & $\mathrm{Y}$ & $\mathbf{N}$ & NA & $\mathbf{N}$ \\
\hline Martini et al., 2004e [44] & $Y$ & $\mathrm{Y}$ & $\mathbf{N}$ & $\mathrm{Y}$ & $\mathbf{N}$ & $\mathbf{N}$ & $\mathbf{N}$ & NA & $Y$ & NA & $\mathrm{Y}$ & $\mathbf{N}$ & NA & $\mathbf{N}$ \\
\hline Martini et al., 2004f [44] & $Y$ & $\mathbf{Y}$ & $\mathbf{N}$ & $\mathbf{Y}$ & $\mathbf{N}$ & $\mathbf{N}$ & $\mathbf{N}$ & NA & $\mathbf{Y}$ & NA & $\mathbf{Y}$ & $\mathbf{N}$ & NA & $\mathbf{N}$ \\
\hline Martini et al., 2004g [44] & $Y$ & $\mathbf{Y}$ & $\mathbf{N}$ & $\mathbf{Y}$ & $\mathbf{N}$ & $\mathbf{N}$ & $\mathbf{N}$ & NA & $\mathbf{Y}$ & NA & $\mathbf{Y}$ & $\mathbf{N}$ & NA & $\mathbf{N}$ \\
\hline Martini et al., 2004h [44] & $\mathrm{Y}$ & $\mathrm{Y}$ & $\mathbf{N}$ & $\mathrm{Y}$ & $\mathbf{N}$ & $\mathbf{N}$ & $\mathbf{N}$ & NA & $\mathrm{Y}$ & NA & $\mathrm{Y}$ & $\mathbf{N}$ & NA & $\mathbf{N}$ \\
\hline Goitein et al., 2005 [43] & $\mathbf{Y}$ & $\mathbf{Y}$ & $\mathbf{Y}$ & $\mathbf{Y}$ & $\mathbf{N}$ & $\mathbf{N}$ & $\mathbf{N}$ & NA & $\mathbf{Y}$ & NA & $\mathbf{Y}$ & $\mathbf{N}$ & NA & $\mathbf{N}$ \\
\hline Gopal et al., 2005 [42] & $\mathbf{Y}$ & $\mathbf{Y}$ & $\mathbf{Y}$ & $Y$ & $Y$ & $\mathbf{N}$ & $\mathbf{N}$ & NA & $\mathbf{Y}$ & NA & $Y$ & $\mathbf{N}$ & NA & $\mathbf{N}$ \\
\hline Castelo-Branco et al., 2007 [68] & $\mathbf{Y}$ & $\mathbf{Y}$ & $\mathbf{Y}$ & $\mathrm{Y}$ & $\mathbf{N}$ & $\mathbf{N}$ & $\mathbf{N}$ & NA & $\mathbf{Y}$ & NA & $\mathrm{Y}$ & $\mathbf{N}$ & NA & $\mathbf{N}$ \\
\hline Landrigan et al., 2008 [41] & $\mathbf{Y}$ & $Y$ & $\mathbf{Y}$ & $Y$ & $Y$ & $\mathbf{N}$ & $\mathbf{N}$ & NA & $\mathbf{Y}$ & NA & $Y$ & $\mathbf{N}$ & NA & $\mathbf{N}$ \\
\hline Ghetti et al., 2009 [40] & $\mathrm{Y}$ & $\mathbf{Y}$ & $\mathbf{N}$ & $\mathrm{Y}$ & $\mathbf{N}$ & $\mathbf{N}$ & $\mathbf{N}$ & NA & $\mathbf{Y}$ & NA & $\mathbf{Y}$ & $\mathbf{N}$ & NA & $\mathbf{N}$ \\
\hline Hill and Smith, 2009 [48] & $\mathbf{Y}$ & $Y$ & $Y$ & $Y$ & $\mathbf{N}$ & $\mathbf{N}$ & $\mathbf{N}$ & NA & $Y$ & NA & $Y$ & $\mathbf{N}$ & NA & $\mathbf{N}$ \\
\hline Sargent et al., 2009 [39] & $\mathbf{Y}$ & $\mathbf{Y}$ & NR & $\mathbf{Y}$ & $\mathbf{N}$ & $\mathbf{N}$ & $\mathbf{N}$ & NA & $\mathbf{Y}$ & NA & $Y$ & $\mathbf{N}$ & NA & $\mathbf{N}$ \\
\hline Blanchard et al., 2010 [67] & $\mathbf{Y}$ & $\mathrm{Y}$ & $\mathbf{Y}$ & $\mathrm{Y}$ & $\mathbf{N}$ & $\mathbf{N}$ & $\mathbf{N}$ & NA & $\mathbf{Y}$ & NA & $\mathbf{Y}$ & $\mathbf{N}$ & NA & $\mathbf{N}$ \\
\hline Campbell et al., 2010 [47] & $\mathrm{Y}$ & $\mathbf{Y}$ & $\mathbf{N}$ & $\mathrm{Y}$ & $\mathbf{N}$ & $\mathrm{Y}$ & $\mathbf{Y}$ & NA & $\mathrm{Y}$ & NA & $\mathrm{Y}$ & $\mathbf{N}$ & NA & $\mathbf{N}$ \\
\hline Ripp et al., 2010 [38] & $\mathbf{Y}$ & $\mathbf{Y}$ & $\mathbf{Y}$ & $\mathbf{Y}$ & $\mathbf{N}$ & $\mathbf{N}$ & $\mathbf{N}$ & NA & $\mathbf{Y}$ & NA & $\mathbf{Y}$ & $\mathbf{N}$ & NA & $\mathbf{N}$ \\
\hline Billings et al., 2011 [37] & $\mathbf{Y}$ & $\mathbf{Y}$ & $\mathbf{N}$ & $\mathbf{Y}$ & $\mathbf{N}$ & $\mathbf{N}$ & $\mathbf{N}$ & NA & $\mathbf{Y}$ & NA & $\mathrm{Y}$ & $\mathbf{N}$ & NA & $\mathbf{Y}$ \\
\hline
\end{tabular}

Figure A1. Cont. 


\begin{tabular}{|c|c|c|c|c|c|c|c|c|c|c|c|c|c|c|}
\hline Criteria/Name & 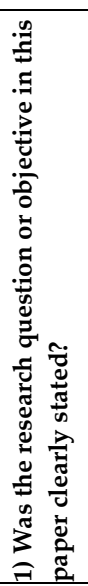 & 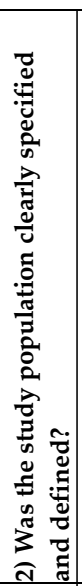 & 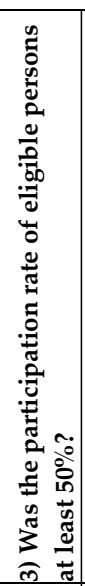 & 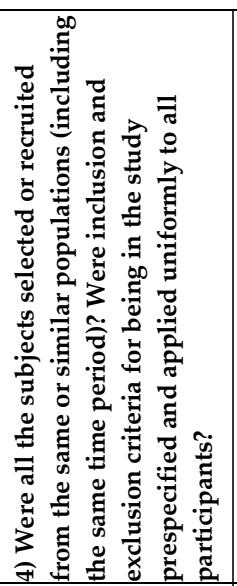 & 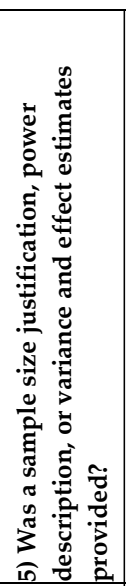 & 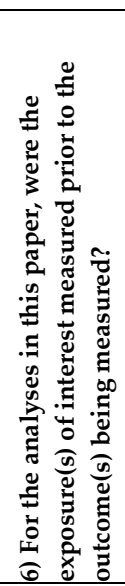 & 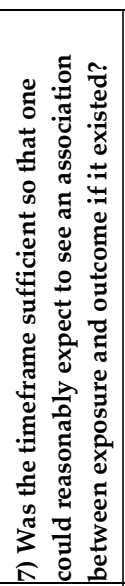 & 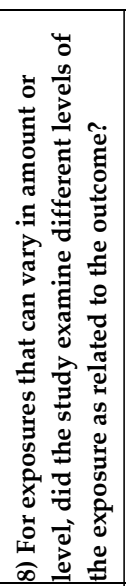 & 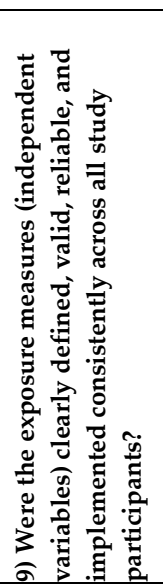 & 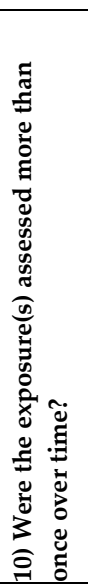 & 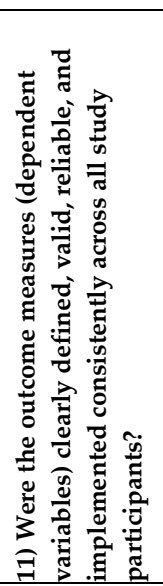 & 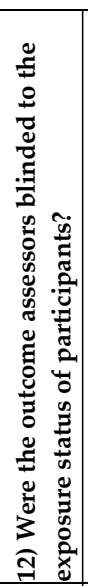 & 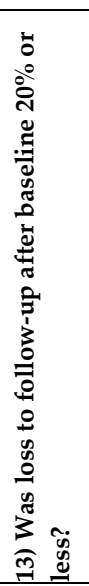 & 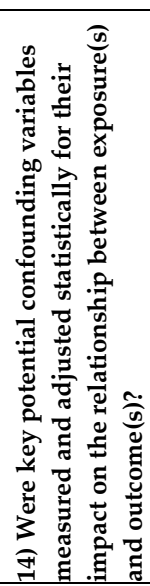 \\
\hline Ripp et al., 2011 [20] & $\mathrm{Y}$ & $\mathrm{Y}$ & $\mathrm{Y}$ & $\mathrm{Y}$ & $\mathbf{N}$ & $\mathrm{Y}$ & $\mathbf{Y}$ & NA & $\mathrm{Y}$ & NA & $Y$ & $\mathbf{N}$ & NA & $\mathbf{N}$ \\
\hline West et al., 2011 [36] & $\mathbf{Y}$ & $\mathrm{Y}$ & $\mathrm{Y}$ & $\mathrm{Y}$ & $\mathbf{N}$ & $\mathbf{N}$ & $\mathbf{N}$ & NA & $\mathbf{Y}$ & NA & $\mathbf{Y}$ & $\mathbf{N}$ & NA & $\mathbf{Y}$ \\
\hline Doolittle et al., 2013 [35] & $\bar{Y}$ & $\bar{Y}$ & $\mathbf{Y}$ & $\mathbf{Y}$ & $\mathbf{Y}$ & $\mathbf{N}$ & $\mathbf{N}$ & NA & $\mathbf{Y}$ & NA & $\mathbf{Y}$ & $\mathbf{N}$ & NA & $\mathbf{N}$ \\
\hline Lebensohn et al., 2013 [34] & $\mathbf{Y}$ & $\mathbf{Y}$ & $\mathbf{Y}$ & $\mathbf{Y}$ & $\mathrm{N}$ & $\mathbf{N}$ & $\mathbf{N}$ & NA & $\mathrm{Y}$ & NA & $\mathbf{Y}$ & $\mathbf{N}$ & NA & $\mathbf{N}$ \\
\hline Shams and El-Masry, 2013 [75] & $\mathbf{Y}$ & $\bar{Y}$ & $\mathbf{Y}$ & $\mathbf{Y}$ & $\mathbf{N}$ & $\mathbf{N}$ & $\mathbf{N}$ & NA & $\mathbf{Y}$ & NA & $\mathbf{Y}$ & $\mathbf{N}$ & NA & $\mathbf{N}$ \\
\hline Aksoy et al., 2014a [70] & $\mathbf{Y}$ & $\mathbf{Y}$ & $\mathbf{Y}$ & $\mathbf{Y}$ & $\mathbf{N}$ & $\mathbf{N}$ & $\mathbf{N}$ & NA & $\mathbf{Y}$ & NA & $\mathbf{Y}$ & $\mathbf{N}$ & NA & $\mathbf{N}$ \\
\hline Aksoy et al., 2014b [70] & $\mathbf{Y}$ & $\mathrm{Y}$ & $\mathbf{Y}$ & $\mathbf{Y}$ & $\mathbf{N}$ & $\mathbf{N}$ & $\mathbf{N}$ & NA & $\mathrm{Y}$ & NA & $\mathrm{Y}$ & $\mathbf{N}$ & NA & $\mathbf{N}$ \\
\hline Arora et al., 2014 [76] & $\mathbf{Y}$ & $\mathbf{Y}$ & $\mathbf{N}$ & $\mathbf{Y}$ & $\mathbf{N}$ & $\mathbf{N}$ & $\mathbf{N}$ & NA & $\mathbf{Y}$ & NA & $\bar{Y}$ & $\mathbf{N}$ & NA & $\mathbf{N}$ \\
\hline Pantaleoni et al., 2014 [33] & $\mathrm{Y}$ & $\mathbf{Y}$ & $\mathbf{Y}$ & $\mathbf{Y}$ & $\mathbf{N}$ & $\mathbf{N}$ & $\mathbf{N}$ & NA & $\mathrm{Y}$ & NA & $\mathbf{Y}$ & $\mathbf{N}$ & NA & $\mathbf{N}$ \\
\hline Rutherford and Oda, 2014 [65] & $\mathbf{Y}$ & $\mathbf{Y}$ & $\mathbf{N}$ & $\mathbf{Y}$ & $\mathbf{N}$ & $\mathbf{N}$ & $\mathbf{N}$ & NA & $\mathbf{Y}$ & NA & $\mathbf{Y}$ & $\mathbf{N}$ & NA & $\mathbf{N}$ \\
\hline Aldrees et al., 2015 [71] & $\mathbf{Y}$ & $\mathbf{Y}$ & $\mathbf{Y}$ & $\mathbf{Y}$ & $\mathbf{N}$ & $\mathbf{N}$ & $\mathbf{N}$ & NA & $\mathbf{Y}$ & NA & $\mathbf{Y}$ & $\mathbf{N}$ & NA & $\mathbf{N}$ \\
\hline Lu et al., 2015 [32] & $\mathbf{Y}$ & $\mathbf{Y}$ & $\mathbf{N}$ & $\mathbf{Y}$ & $\mathbf{N}$ & $\mathbf{N}$ & $\mathbf{N}$ & NA & $\bar{Y}$ & NA & $\mathbf{Y}$ & $\mathbf{N}$ & NA & $\mathbf{N}$ \\
\hline Shapiro et al., 2015 [58] & $\mathbf{Y}$ & $\mathbf{Y}$ & $\mathbf{Y}$ & $\mathbf{Y}$ & $\mathbf{N}$ & $\mathbf{N}$ & $\mathbf{N}$ & NA & $\mathbf{Y}$ & NA & $\mathbf{Y}$ & $\mathbf{N}$ & NA & $\mathrm{Y}$ \\
\hline Ripp et al., 2015a [63] & $\mathbf{Y}$ & $\mathbf{Y}$ & $\mathbf{Y}$ & $\mathbf{N}$ & $\mathbf{Y}$ & $\mathbf{N}$ & $\mathbf{N}$ & NA & $\mathrm{Y}$ & NA & $\mathrm{Y}$ & $\mathbf{N}$ & NA & $\mathbf{N}$ \\
\hline Ripp et al., 2015b [63] & $\mathbf{Y}$ & $\mathrm{Y}$ & $\mathbf{Y}$ & $\mathbf{N}$ & $\mathbf{Y}$ & $\mathbf{N}$ & $\mathbf{N}$ & NA & $\mathrm{Y}$ & NA & $\mathbf{Y}$ & $\mathbf{N}$ & NA & $\mathbf{N}$ \\
\hline Cubero et al., 2016 [77] & $\mathbf{Y}$ & $\mathbf{Y}$ & $\mathbf{N}$ & $\mathbf{Y}$ & $\mathbf{N}$ & $\mathbf{Y}$ & $\mathbf{Y}$ & NA & $\mathbf{Y}$ & NA & $\mathbf{Y}$ & $\mathbf{N}$ & NA & $\mathbf{N}$ \\
\hline Lin et al., 2016 [62] & $\mathbf{Y}$ & $\mathbf{Y}$ & $Y$ & $\mathbf{Y}$ & $\mathbf{N}$ & $\mathbf{N}$ & $\mathbf{N}$ & NA & $Y$ & NA & $\mathbf{Y}$ & $\mathbf{N}$ & NA & $\mathbf{N}$ \\
\hline Spataro et al., 2016 [61] & $Y$ & $Y$ & $Y$ & $Y$ & $\mathbf{N}$ & $\mathbf{N}$ & $\mathbf{N}$ & NA & $Y$ & NA & $Y$ & $\mathbf{N}$ & NA & $\mathbf{N}$ \\
\hline Kwah et al., 2016 [73] & $Y$ & $Y$ & $Y$ & $Y$ & $\mathbf{N}$ & $\mathbf{N}$ & $\mathbf{N}$ & NA & $Y$ & NA & $Y$ & $\mathbf{N}$ & NA & $\mathbf{N}$ \\
\hline Ripp et al., 2016 [60] & $Y$ & $\mathbf{Y}$ & $\mathbf{Y}$ & $\mathbf{Y}$ & $\mathbf{N}$ & $\mathbf{N}$ & $\mathbf{N}$ & NA & $\mathbf{Y}$ & NA & $\mathbf{Y}$ & $\mathbf{N}$ & NA & $\mathbf{N}$ \\
\hline Winkel et al., 2016 [59] & $\mathbf{Y}$ & $\mathbf{Y}$ & $\mathbf{Y}$ & $\mathbf{Y}$ & $\mathbf{Y}$ & $\mathbf{N}$ & $\mathbf{N}$ & NA & $\mathbf{Y}$ & NA & $\mathbf{Y}$ & $\mathbf{N}$ & NA & $\mathbf{N}$ \\
\hline
\end{tabular}

Figure A1. Cont. 


\begin{tabular}{|c|c|c|c|c|c|c|c|c|c|c|c|c|c|c|}
\hline Criteria/Name & 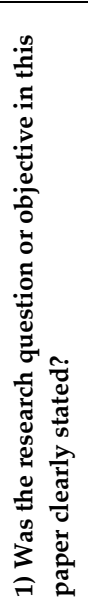 & 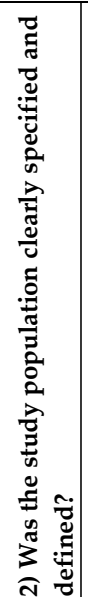 & 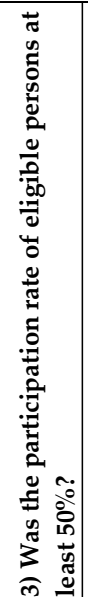 & 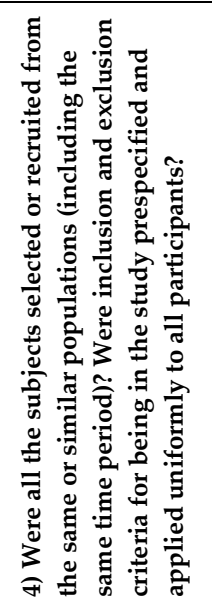 & 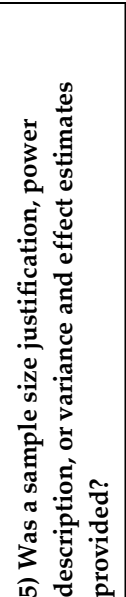 & 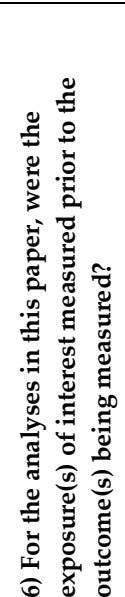 & 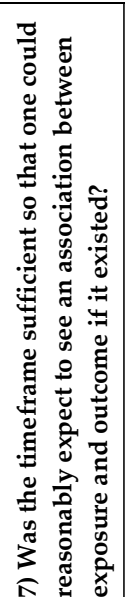 & 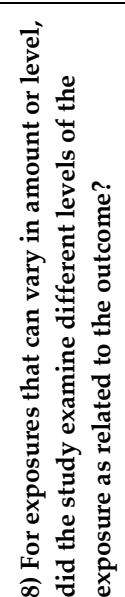 & 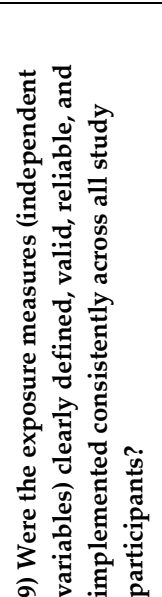 & 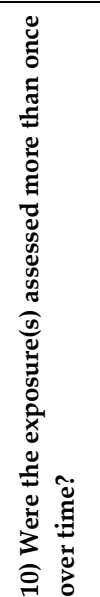 & 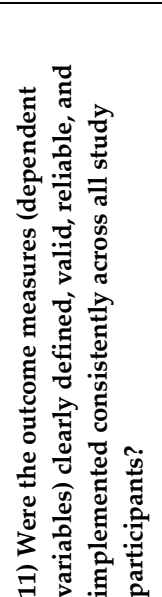 & 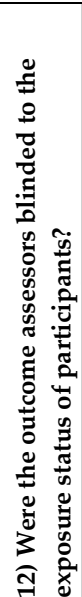 & 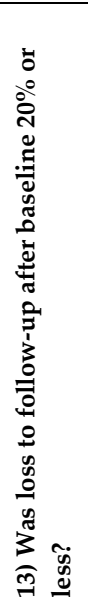 & 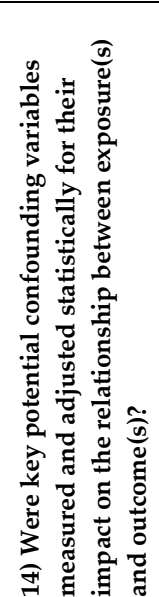 \\
\hline Zubairi and Noordin, 2016a [72] & $Y$ & $Y$ & $\mathrm{Y}$ & $\mathbf{Y}$ & $\mathbf{N}$ & $\mathbf{N}$ & $\mathbf{N}$ & NA & $\mathrm{Y}$ & NA & $\mathrm{Y}$ & $\mathbf{N}$ & NA & $\mathbf{N}$ \\
\hline Zubairi and Noordin, 2016b [72] & $\mathbf{Y}$ & $\mathbf{Y}$ & $\mathbf{Y}$ & $\mathbf{Y}$ & $\mathbf{N}$ & $\mathbf{N}$ & $\mathbf{N}$ & NA & $\mathbf{Y}$ & NA & $\mathbf{Y}$ & $\mathbf{N}$ & NA & $\mathbf{N}$ \\
\hline Zubairi and Noordin, 2016c [72] & $\mathbf{Y}$ & $\mathbf{Y}$ & $\mathbf{Y}$ & $\mathbf{Y}$ & $\mathbf{N}$ & $\mathbf{N}$ & $\mathbf{N}$ & NA & $\mathbf{Y}$ & NA & $\mathbf{Y}$ & $\mathbf{N}$ & NA & $\mathbf{N}$ \\
\hline Zubairi and Noordin, 2016d [72] & $\mathrm{Y}$ & $\mathrm{Y}$ & $\mathbf{Y}$ & $\mathbf{Y}$ & $\mathbf{N}$ & $\mathbf{N}$ & $\mathbf{N}$ & NA & $\mathbf{Y}$ & NA & $\mathrm{Y}$ & $\mathbf{N}$ & NA & $\mathbf{N}$ \\
\hline Zubairi and Noordin, 2016e [72] & $\mathbf{Y}$ & $\mathrm{Y}$ & $\mathbf{Y}$ & $\mathbf{Y}$ & $\mathbf{N}$ & $\mathbf{N}$ & $\mathbf{N}$ & NA & $\mathbf{Y}$ & NA & $\mathbf{Y}$ & $\mathbf{N}$ & NA & $\mathbf{N}$ \\
\hline Attenello et al., 2017 [66] & $\mathbf{Y}$ & $\mathrm{Y}$ & $\mathbf{N}$ & $\mathbf{Y}$ & $\mathbf{N}$ & $\mathbf{N}$ & $\mathbf{N}$ & NA & $\mathbf{Y}$ & NA & $\mathbf{Y}$ & $\mathbf{N}$ & NA & $\mathbf{N}$ \\
\hline Baer et al., 2017 [57] & $\mathrm{Y}$ & $\mathrm{Y}$ & $\mathbf{Y}$ & $\mathbf{Y}$ & $\mathbf{N}$ & $\mathbf{N}$ & $\mathbf{N}$ & NA & $\mathrm{Y}$ & NA & $\mathrm{Y}$ & $\mathbf{N}$ & NA & $\mathbf{Y}$ \\
\hline Braun et al. 2017 [64] & $\mathbf{Y}$ & $\mathbf{Y}$ & $\mathbf{N}$ & $\mathbf{Y}$ & $\mathbf{N}$ & $\mathbf{N}$ & $\mathbf{N}$ & NA & $\mathbf{Y}$ & NA & $\mathrm{Y}$ & $\mathbf{N}$ & NA & $\mathbf{N}$ \\
\hline Busis et al., 2017 [54] & $\mathbf{Y}$ & $\mathbf{Y}$ & $\mathbf{N}$ & $\mathbf{Y}$ & $\mathbf{N}$ & $\mathbf{N}$ & $\mathbf{N}$ & NA & $\mathbf{Y}$ & NA & $\mathbf{Y}$ & $\mathbf{N}$ & NA & $\mathbf{N}$ \\
\hline Chaukos et al., 2017 [56] & $\mathbf{Y}$ & $\mathbf{Y}$ & $\mathrm{Y}$ & $\mathbf{Y}$ & $\mathbf{N}$ & $\mathbf{N}$ & $\mathbf{N}$ & NA & $\mathbf{Y}$ & NA & $\mathbf{Y}$ & $\mathbf{N}$ & NA & $\mathbf{N}$ \\
\hline Guenette and Smith, 2017 [55] & $\mathbf{Y}$ & $\mathrm{Y}$ & $\mathbf{N}$ & $\mathbf{Y}$ & $\mathbf{N}$ & $\mathbf{N}$ & $\mathbf{N}$ & NA & $\mathbf{Y}$ & NA & $\mathbf{Y}$ & $\mathbf{N}$ & NA & $\mathbf{N}$ \\
\hline Ramey et al., 2017 [53] & $\mathrm{Y}$ & $\mathrm{Y}$ & $\mathbf{N}$ & $\mathbf{Y}$ & $\mathbf{N}$ & $\mathbf{N}$ & $\mathbf{N}$ & NA & $\mathrm{Y}$ & NA & $\mathrm{Y}$ & $\mathbf{N}$ & NA & $\mathbf{N}$ \\
\hline Shakir et al., 2017 [52] & $\mathbf{Y}$ & $\mathbf{Y}$ & $\mathbf{N}$ & $\mathbf{Y}$ & $\mathbf{N}$ & $\mathbf{N}$ & $\mathbf{N}$ & NA & $\mathbf{Y}$ & NA & $\mathbf{Y}$ & $\mathbf{N}$ & NA & $\mathbf{N}$ \\
\hline Slavin et al., 2017 [51] & $\mathbf{Y}$ & $\mathbf{Y}$ & NR & $\mathbf{Y}$ & $\mathbf{N}$ & $\mathbf{N}$ & $\mathbf{N}$ & NA & $\mathbf{Y}$ & NA & $\mathbf{Y}$ & $\mathbf{N}$ & NA & $\mathbf{N}$ \\
\hline Waheed et al., 2017 [74] & $\mathbf{Y}$ & $\mathbf{Y}$ & NR & $\mathbf{Y}$ & $\mathbf{N}$ & $\mathbf{N}$ & $\mathbf{N}$ & NA & $\mathbf{Y}$ & NA & $\mathbf{Y}$ & $\mathbf{N}$ & NA & $\mathbf{N}$ \\
\hline Yrondi et al., 2017a [69] & $\mathrm{Y}$ & $\mathrm{Y}$ & NR & $\mathrm{Y}$ & $\mathbf{Y}$ & $\mathbf{N}$ & $\mathbf{N}$ & NA & $\mathrm{Y}$ & NA & $\mathrm{Y}$ & $\mathbf{N}$ & NA & $\mathbf{N}$ \\
\hline Yrondi et al., 2017b [69] & $\mathbf{Y}$ & $\mathbf{Y}$ & NR & $\mathbf{Y}$ & $\mathbf{Y}$ & $\mathbf{N}$ & $\mathbf{N}$ & NA & $\mathbf{Y}$ & NA & $\mathbf{Y}$ & $\mathbf{N}$ & NA & $\mathbf{N}$ \\
\hline Lebares et al., 2018 [50] & $\mathbf{Y}$ & $\mathbf{Y}$ & $\mathbf{N}$ & $\mathbf{Y}$ & $\mathbf{N}$ & $\mathbf{N}$ & $\mathbf{N}$ & NA & $\mathbf{Y}$ & NA & $\mathbf{Y}$ & $\mathbf{N}$ & NA & $\mathbf{N}$ \\
\hline Shoimer et al., 2018 [49] & $\mathrm{Y}$ & $\mathrm{Y}$ & $\mathrm{Y}$ & $\mathrm{Y}$ & $\mathrm{N}$ & $\mathbf{N}$ & $\mathbf{N}$ & NA & $\mathrm{Y}$ & NA & $\mathrm{Y}$ & $\mathbf{N}$ & NA & $\mathbf{N}$ \\
\hline
\end{tabular}

Figure A1. Summary of quality assessment of included studies. Y: Yes; N: No; NA: not applicable; NR: not reported. 


\section{References}

1. Freudenberger, H.J. Staff Burn-Out. J. Soc. Issues 1974, 30, 159-165. [CrossRef]

2. Jackson, S.E.; Schwab, R.L.; Schuler, R.S. Toward an understanding of the burnout phenomenon. J. Appl. Psychol. 1986, 71, 630-640. [CrossRef]

3. Maslach, C.; Jackson, S.; Leiter, M. The Maslach Burnout Inventory Manual; Consulting Psychologists Press: Palo Alto, CA, USA, 1997; Volume 3, pp. 191-218.

4. Maslach, C.; Leiter, M.P. Understanding the burnout experience: Recent research and its implications for psychiatry. World Psychiatry Off. J. World Psychiatr. Assoc. (WPA) 2016, 15, 103-111. [CrossRef] [PubMed]

5. Golonka, K.; Mojsa-Kaja, J.; Gawlowska, M.; Popiel, K. Cognitive Impairments in Occupational Burnout-Error Processing and Its Indices of Reactive and Proactive Control. Front. Psychol. 2017, 8, 676. [CrossRef]

6. Kang, E.K.; Lihm, H.S.; Kong, E.H. Association of intern and resident burnout with self-reported medical errors. Korean J. Fam. Med. 2013, 34, 36-42. [CrossRef] [PubMed]

7. Kluger, M.T.; Townend, K.; Laidlaw, T. Job satisfaction, stress and burnout in Australian specialist anaesthetists. Anaesthesia 2003, 58, 339-345. [CrossRef]

8. Williams, E.S.; Konrad, T.R.; Scheckler, W.E.; Pathman, D.E.; Linzer, M.; McMurray, J.E.; Gerrity, M.; Schwartz, M. Understanding physicians' intentions to withdraw from practice: The role of job satisfaction, job stress, mental and physical health. 2001. Health Care Manag. Rev. 2010, 35, 105-115. [CrossRef] [PubMed]

9. Dewa, C.S.; Loong, D.; Bonato, S.; Trojanowski, L.; Rea, M. The relationship between resident burnout and safety-related and acceptability-related quality of healthcare: A systematic literature review. BMC Med. Educ. 2017, 17, 195. [CrossRef]

10. Williams, E.S.; Skinner, A.C. Outcomes of physician job satisfaction: A narrative review, implications, and directions for future research. Health Care Manag. Rev. 2003, 28, 119-139. [CrossRef]

11. West, C.P.; Shanafelt, T.D. Physician well-being and professionalism. Minn. Med. 2007, 90, 44-46.

12. Wurm, W.; Vogel, K.; Holl, A.; Ebner, C.; Bayer, D.; Morkl, S.; Szilagyi, I.S.; Hotter, E.; Kapfhammer, H.P.; Hofmann, P. Depression-Burnout Overlap in Physicians. PLoS ONE 2016, 11, e0149913. [CrossRef]

13. Rosenstein, A.H.; O'Daniel, M. Impact and implications of disruptive behavior in the perioperative arena. J. Am. Coll. Surg. 2006, 203, 96-105. [CrossRef]

14. Ledikwe, J.H.; Kleinman, N.J.; Mpho, M.; Mothibedi, H.; Mawandia, S.; Semo, B.W.; O’Malley, G. Associations between healthcare worker participation in workplace wellness activities and job satisfaction, occupational stress and burnout: A cross-sectional study in Botswana. BMJ Open 2018, 8, e018492. [CrossRef]

15. Dyrbye, L.N.; Thomas, M.R.; Massie, F.S.; Power, D.V.; Eacker, A.; Harper, W.; Durning, S.; Moutier, C.; Szydlo, D.W.; Novotny, P.J.; et al. Burnout and suicidal ideation among U.S. medical students. Ann. Intern. Med. 2008, 149, 334-341. [CrossRef]

16. Shanafelt, T.D.; Balch, C.M.; Bechamps, G.J.; Russell, T.; Dyrbye, L.; Satele, D.; Collicott, P.; Novotny, P.J.; Sloan, J.; Freischlag, J.A. Burnout and career satisfaction among American surgeons. Ann. Surg. 2009, 250, 463-471. [CrossRef]

17. Kumar, S. Burnout and doctors: Prevalence, prevention and intervention. Healthcare 2016, 4, 37. [CrossRef]

18. Moradi, Y.; Baradaran, H.R.; Yazdandoost, M.; Atrak, S.; Kashanian, M. Prevalence of Burnout in residents of obstetrics and gynecology: A systematic review and meta-analysis. Med. J. Islamic Repub. Iran 2015, $29,235$.

19. Sanfilippo, F.; Noto, A.; Foresta, G.; Santonocito, C.; Palumbo, G.J.; Arcadipane, A.; Maybauer, D.M.; Maybauer, M.O. Incidence and Factors Associated with Burnout in Anesthesiology: A Systematic Review. BioMed Res. Int. 2017, 2017, 8648925. [CrossRef]

20. Ripp, J.; Babyatsky, M.; Fallar, R.; Bazari, H.; Bellini, L.; Kapadia, C.; Katz, J.T.; Pecker, M.; Korenstein, D. The incidence and predictors of job burnout in first-year internal medicine residents: A five-institution study. Acad. Med. 2011, 86, 1304-1310. [CrossRef]

21. Moher, D.; Liberati, A.; Tetzlaff, J.; Altman, D.G.; The PRISMA Group. Preferred Reporting Items for Systematic Reviews and Meta-Analyses: The PRISMA Statement. PLoS Med. 2009, 6, e1000097. [CrossRef]

22. Maslach, C.; Jackson, S.E.; Leiter, M.P.; Schaufeli, W.B.; Schwab, R.L. Maslach Burnout Inventory; Consulting Psychologists Press: Palo Alto, CA, USA, 1986; Volume 21.

23. Agency for Healthcare Research and Quality. Physician Burnout. Available online: https://www.ahrq.gov/ professionals/clinicians-providers/ahrq.../burnout/index.html (accessed on 17 April 2019). 
24. National Heart, L.; Institute, B. Quality Assessment Tool for Observational Cohort and Cross-Sectional Studies; National Institutes of Health, Department of Health and Human Services: Bethesda, MD, USA, 2014.

25. Cheung, M.W.L.; Ho, R.C.; Lim, Y.; Mak, A. Conducting a meta-analysis: Basics and good practices. Int. J. Rheum. Dis. 2012, 15, 129-135. [CrossRef]

26. Lim, G.Y.; Tam, W.W.; Lu, Y.; Ho, C.S.; Zhang, M.W.; Ho, R.C. Prevalence of Depression in the Community from 30 Countries between 1994 and 2014. Sci. Rep. 2018, 8, 2861. [CrossRef]

27. Quek, Y.H.; Tam, W.W.; Zhang, M.W.; Ho, R.C. The global prevalence of anxiety and depressive symptoms among caregivers of stroke survivors. J. Am. Med. Dir. Assoc. 2017, 18, 111-116.

28. Quek, Y.-H.; Tam, W.W.S.; Zhang, M.W.B.; Ho, R.C.M. Exploring the association between childhood and adolescent obesity and depression: A meta-analysis. Obes. Rev. 2017, 18, 742-754. [CrossRef]

29. Tung, Y.-J.; Lo, K.K.; Ho, R.C.; Tam, W.S.W. Prevalence of depression among nursing students: A systematic review and meta-analysis. Nurse Educ. Today 2018, 63, 119-129. [CrossRef]

30. Mak, A.; Cheung, M.W.; Fu, E.H.; Ho, R.C. Meta-analysis in medicine: An introduction. Int. J. Rheum. Dis. 2010, 13, 101-104. [CrossRef]

31. Puthran, R.; Zhang, M.W.; Tam, W.W.; Ho, R.C. Prevalence of depression amongst medical students: A meta-analysis. Med. Educ. 2016, 50, 456-468. [CrossRef]

32. Lu, D.W.; Dresden, S.; McCloskey, C.; Branzetti, J.; Gisondi, M.A. Impact of burnout on self-reported patient care among emergency physicians. West. J. Emerg. Med. 2015, 16, 996. [CrossRef]

33. Pantaleoni, J.L.; Augustine, E.M.; Sourkes, B.M.; Bachrach, L.K. Burnout in pediatric residents over a 2-year period: A longitudinal study. Acad. Pediatr. 2014, 14, 167-172. [CrossRef]

34. Lebensohn, P.; Dodds, S.; Benn, R.; Brooks, A.J.; Birch, M. Resident wellness behaviors. Fam. Med. 2013, 45, 541-549.

35. Doolittle, B.R.; Windish, D.M.; Seelig, C.B. Burnout, coping, and spirituality among internal medicine resident physicians. J. Grad. Med. Educ. 2013, 5, 257-261. [CrossRef] [PubMed]

36. West, C.P.; Shanafelt, T.D.; Kolars, J.C. Quality of life, burnout, educational debt, and medical knowledge among internal medicine residents. JAMA 2011, 306, 952-960. [CrossRef]

37. Billings, M.E.; Lazarus, M.E.; Wenrich, M.; Curtis, J.R.; Engelberg, R.A. The effect of the hidden curriculum on resident burnout and cynicism. J. Grad. Med. Educ. 2011, 3, 503-510. [CrossRef] [PubMed]

38. Ripp, J.; Fallar, R.; Babyatsky, M.; David, R.; Reich, L.; Korenstein, D. Prevalence of resident burnout at the start of training. Teach. Learn. Med. 2010, 22, 172-175. [CrossRef] [PubMed]

39. Sargent, M.C.; Sotile, W.; Sotile, M.O.; Rubash, H.; Barrack, R.L. Quality of life during orthopaedic training and academic practice: Part 1: Orthopaedic surgery residents and faculty. JBJS 2009, 91, 2395-2405. [CrossRef] [PubMed]

40. Ghetti, C.; Chang, J.; Gosman, G. Burnout, psychological skills, and empathy: Balint training in obstetrics and gynecology residents. J. Grad. Med. Educ. 2009, 1, 231-235. [CrossRef] [PubMed]

41. Landrigan, C.P.; Fahrenkopf, A.M.; Lewin, D.; Sharek, P.J.; Barger, L.K.; Eisner, M.; Edwards, S.; Chiang, V.W.; Wiedermann, B.L.; Sectish, T.C. Effects of the accreditation council for graduate medical education duty hour limits on sleep, work hours, and safety. Pediatrics 2008, 122, 250-258. [CrossRef] [PubMed]

42. Gopal, R.; Glasheen, J.J.; Miyoshi, T.J.; Prochazka, A.V. Burnout and internal medicine resident work-hour restrictions. Arch. Intern. Med. 2005, 165, 2595-2600. [CrossRef] [PubMed]

43. Goitein, L.; Shanafelt, T.D.; Wipf, J.E.; Slatore, C.G.; Back, A.L. The effects of work-hour limitations on resident well-being, patient care, and education in an internal medicine residency program. Arch. Intern. Med. 2005, 165, 2601-2606. [CrossRef]

44. Martini, S.; Arfken, C.L.; Churchill, A.; Balon, R. Burnout comparison among residents in different medical specialties. Acad. Psychiatry 2004, 28, 240-242. [CrossRef]

45. Garza, J.A.; Schneider, K.M.; Promecene, P.; Monga, M. Burnout in residency: A statewide study. South. Med. J. 2004, 97, 1171-1174. [CrossRef]

46. Gelfand, D.V.; Podnos, Y.D.; Carmichael, J.C.; Saltzman, D.J.; Wilson, S.E.; Williams, R.A. Effect of the 80-hour workweek on resident burnout. Arch. Surg. 2004, 139, 933-940. [CrossRef]

47. Campbell, J.; Prochazka, A.V.; Yamashita, T.; Gopal, R. Predictors of persistent burnout in internal medicine residents: A prospective cohort study. Acad. Med. 2010, 85, 1630-1634. [CrossRef]

48. Hill, J.D.; Smith, R.J. Monitoring stress levels in postgraduate medical training. Laryngoscope 2009, 119, 75-78. [CrossRef] 
49. Shoimer, I.; Patten, S.; Mydlarski, P. Burnout in dermatology residents: A Canadian perspective. Br. J. Dermatol. 2018, 178, 270-271. [CrossRef]

50. Lebares, C.C.; Guvva, E.V.; Ascher, N.L.; O'Sullivan, P.S.; Harris, H.W.; Epel, E.S. Burnout and Stress among US Surgery Residents: Psychological Distress and Resilience. J. Am. Coll. Surg. 2018, 226, 80-90. [CrossRef]

51. Slavin, S.; Shoss, M.; Broom, M.A. A Program to Prevent Burnout, Depression, and Anxiety in First-Year Pediatric Residents. Acad. Pediatr. 2017, 17, 456-458. [CrossRef]

52. Shakir, H.J.; McPheeters, M.J.; Shallwani, H.; Pittari, J.E.; Reynolds, R.M. The Prevalence of Burnout Among US Neurosurgery Residents. Neurosurgery 2017, 83, 582-590. [CrossRef]

53. Ramey, S.J.; Ahmed, A.A.; Takita, C.; Wilson, L.D.; Thomas, C.R.; Yechieli, R. Burnout Evaluation of Radiation Residents Nationwide: Results of a Survey of United States Residents. Int. J. Radiat. Oncol. Boil. Phys. 2017, 99, 530-538. [CrossRef]

54. Busis, N.A.; Shanafelt, T.D.; Keran, C.M.; Levin, K.H.; Schwarz, H.B.; Molano, J.R.; Vidic, T.R.; Kass, J.S.; Miyasaki, J.M.; Sloan, J.A. Burnout, career satisfaction, and well-being among US neurologists in 2016. Neurology 2017, 88, 797-808. [CrossRef]

55. Guenette, J.P.; Smith, S.E. Burnout: Prevalence and associated factors among radiology residents in New England with comparison against United States resident physicians in other specialties. Am. J. Roentgenol. 2017, 209, 136-141. [CrossRef] [PubMed]

56. Chaukos, D.; Chad-Friedman, E.; Mehta, D.H.; Byerly, L.; Celik, A.; McCoy, T.H.; Denninger, J.W. Risk and resilience factors associated with resident burnout. Acad. Psychiatry 2017, 41, 189-194. [CrossRef] [PubMed]

57. Baer, T.E.; Feraco, A.M.; Sagalowsky, S.T.; Williams, D.; Litman, H.J.; Vinci, R.J. Pediatric resident burnout and attitudes toward patients. Pediatrics 2017, 139, e20162163. [CrossRef]

58. Shapiro, J.; Zhang, B.; Warm, E.J. Residency as a social network: Burnout, loneliness, and social network centrality. J. Grad. Med. Educ. 2015, 7, 617-623. [CrossRef]

59. Winkel, A.F.; Feldman, N.; Moss, H.; Jakalow, H.; Simon, J.; Blank, S. Narrative medicine workshops for obstetrics and gynecology residents and association with burnout measures. Obstet. Gynecol. 2016, 128, 27S-33S. [CrossRef]

60. Ripp, J.A.; Fallar, R.; Korenstein, D. A randomized controlled trial to decrease job burnout in first-year internal medicine residents using a facilitated discussion group intervention. J. Grad. Med. Educ. 2016, 8, 256-259. [CrossRef] [PubMed]

61. Spataro, B.M.; Tilstra, S.A.; Rubio, D.M.; McNeil, M.A. The toxicity of self-blame: Sex differences in burnout and coping in internal medicine trainees. J. Womens Health 2016, 25, 1147-1152. [CrossRef] [PubMed]

62. Lin, D.T.; Liebert, C.A.; Tran, J.; Lau, J.N.; Salles, A. Emotional intelligence as a predictor of resident well-being. J. Am. Coll. Surg. 2016, 223, 352-358. [CrossRef] [PubMed]

63. Ripp, J.A.; Bellini, L.; Fallar, R.; Bazari, H.; Katz, J.T.; Korenstein, D. The impact of duty hours restrictions on job burnout in internal medicine residents: A three-institution comparison study. Acad. Med. 2015, 90, 494-499. [CrossRef] [PubMed]

64. Braun, S.E.; Auerbach, S.M.; Rybarczyk, B.; Lee, B.; Call, S. Mindfulness, burnout, and effects on performance evaluations in internal medicine residents. Adv. Med. Educ. Pract. 2017, 8, 591-597. [CrossRef]

65. Rutherford, K.; Oda, J. Family medicine residency training and burnout: A qualitative study. Can. Med. Educ. J. 2014, 5, e13.

66. Attenello, F.J.; Buchanan, I.A.; Wen, T.; Donoho, D.A.; McCartney, S.; Cen, S.Y.; Khalessi, A.A.; Cohen-Gadol, A.A.; Cheng, J.S.; Mack, W.J. Factors associated with burnout among US neurosurgery residents: A nationwide survey. J. Neurosurg. 2018, 129, 1349-1363. [CrossRef]

67. Blanchard, P.; Truchot, D.; Albiges-Sauvin, L.; Dewas, S.; Pointreau, Y.; Rodrigues, M.; Xhaard, A.; Loriot, Y.; Giraud, P.; Soria, J. Prevalence and causes of burnout amongst oncology residents: A comprehensive nationwide cross-sectional study. Eur. J. Cancer 2010, 46, 2708-2715. [CrossRef]

68. Castelo-Branco, C.; Figueras, F.; Eixarch, E.; Quereda, F.; Cancelo, M.; Gonzalez, S.; Balasch, J. Stress symptoms and burnout in obstetric and gynaecology residents. BJOG Int. J. Obstet. Gynaecol. 2007, 114, 94-98. [CrossRef]

69. Yrondi, A.; Fournier, C.; Fourcade, O.; Schmitt, L. Burnout compared between anaesthesiology and psychiatry residents in France: An observational study. Eur. J. Anaesthesiol. (EJA) 2017, 34, 480-482. [CrossRef] 
70. Yazgan Aksoy, D.; Durusu Tanriover, M.; Unal, S.; Dizdar, O.; Kalyoncu, U.; Karakaya, J.; Unal, S.; Kale, G. Burnout syndrome during residency in internal medicine and pediatrics in a country without working time directive. Int. J. Health Care Qual. Assur. 2014, 27, 223-230. [CrossRef]

71. Aldrees, T.; Badri, M.; Islam, T.; Alqahtani, K. Burnout among otolaryngology residents in Saudi Arabia: A multicenter study. J. Surg. Educ. 2015, 72, 844-848. [CrossRef]

72. Zubairi, A.J.; Noordin, S. Factors associated with burnout among residents in a developing country. Ann. Med. Surg. 2016, 6, 60-63. [CrossRef]

73. Kwah, J.; Weintraub, J.; Fallar, R.; Ripp, J. The Effect of Burnout on Medical Errors and Professionalism in First-Year Internal Medicine Residents. J. Grad. Med. Educ. 2016, 8, 597-600. [CrossRef]

74. Waheed, K.; Liaqat, N.; Ejaz, S.; Khanum, A.; Ijaz, S.; Butt, A.; Randhawa, F.A.; Naheed, I.; Javed, S. Burnout among gynaecological residents in Lahore, Pakistan: A cross-sectional survey. Age 2017, 27, 1-69.

75. Shams, T.; El-Masry, R. Job stress and burnout among academic career anaesthesiologists at an Egyptian University Hospital. Sultan Qaboos Univ. Med. J. 2013, 13, 287. [CrossRef] [PubMed]

76. Arora, M.; Diwan, A.D.; Harris, I.A. Prevalence and factors of burnout among Australian orthopaedic trainees: A cross-sectional study. J. Orthop. Surg. 2014, 22, 374-377. [CrossRef] [PubMed]

77. Cubero, D.I.; Fumis, R.R.L.; de Sá, T.H.; Dettino, A.; Costa, F.O.; Van Eyll, B.M.A.; Beato, C.; Peria, F.M.; Mota, A.; Altino, J. Burnout in medical oncology fellows: A prospective multicenter cohort study in Brazilian institutions. J. Cancer Educ. 2016, 31, 582-587. [CrossRef] [PubMed]

78. Hughes, D.; Burke, D.; Hickie, I.; Wilson, A.; Tobin, M. Advanced training in adult psychiatry. Australas. Psychiatry 2002, 10, 6-10. [CrossRef]

79. Momoh, P. Medical Ethics Manual; World Medical Association: Ferney-Voltaire, France, 2006.

80. Myers, M.F. Physician impairment: Is it relevant to academic psychiatry? Acad. Psychiatry 2008, 32, 39-43. [CrossRef] [PubMed]

81. Hauer, A.; Waukau, H.J.; Welch, P. Physician Burnout in Wisconsin: An Alarming Trend Affecting Physician Wellness. WMJ Off. Publ. State Med. Soc. Wis. 2018, 117, 194-200.

82. Liew, C. The future of radiology augmented with Artificial Intelligence: A strategy for success. Eur. J. Radiol. 2018, 102, 152-156. [CrossRef]

83. Erschens, R.; Keifenheim, K.E.; Herrmann-Werner, A.; Loda, T.; Schwille-Kiuntke, J.; Bugaj, T.J.; Nikendei, C.; Huhn, D.; Zipfel, S.; Junne, F. Professional burnout among medical students: Systematic literature review and meta-analysis. Med. Teach. 2018, 41, 172-183. [CrossRef]

84. Freischlag, J.A. Burnout and Depression Among General Surgery Residents: Image Is Everything-It Alters Perception. JAMA Surg. 2018, 153, 711. [CrossRef]

85. Lee, Y.; Rosenblat, J.D.; Lee, J.; Carmona, N.E.; Subramaniapillai, M.; Shekotikhina, M.; Mansur, R.B.; Brietzke, E.; Lee, J.-H.; Ho, R.C. Efficacy of antidepressants on measures of workplace functioning in major depressive disorder: A systematic review. J. Affect. Disord. 2017, 227, 406-415. [CrossRef]

86. Monsalve-Reyes, C.S.; San Luis-Costas, C.; Gómez-Urquiza, J.L.; Albendín-García, L.; Aguayo, R.; Cañadas-De la Fuente, G.A. Burnout syndrome and its prevalence in primary care nursing: A systematic review and meta-analysis. BMC Fam. Pract. 2018, 19, 59. [CrossRef]

87. Shanafelt, T.D.; Hasan, O.; Dyrbye, L.N.; Sinsky, C.; Satele, D.; Sloan, J.; West, C.P. Changes in Burnout and Satisfaction with Work-Life Balance in Physicians and the General US Working Population Between 2011 and 2014. Mayo Clin. Proc. 2015, 90, 1600-1613. [CrossRef]

88. Ogawa, R.; Seo, E.; Maeno, T.; Ito, M.; Sanuki, M.; Maeno, T. The relationship between long working hours and depression among first-year residents in Japan. BMC Med. Educ. 2018, 18, 50. [CrossRef]

89. Ebrahimi, S.; Kargar, Z. Occupational stress among medical residents in educational hospitals. Ann. Occup. Environ. Med. 2018, 30, 51. [CrossRef]

90. Temple, J. Resident duty hours around the globe: Where are we now? BMC Med. Educ. 2014, 14, S8. [CrossRef]

91. Nasca, T.J. Summary of Changes to ACGME Common Program Requirements Section VI. Available online: http://www.acgme.org/Portals/0/PDFs/Nasca-Community/Section-VI-Memo-3-10-17.pdf (accessed on 9 May 2018).

92. Fargen, K.M.; Rosen, C.L. Are Duty Hour Regulations Promoting a Culture of Dishonesty among Resident Physicians? J. Grad. Med. Educ. 2013, 5, 553-555. [CrossRef] 
93. Siu, C.; Yuen, S.K.; Cheung, A. Burnout among public doctors in Hong Kong: Cross-sectional survey. Hong Kong Med. J. = Xianggang Yi Xue Za Zhi 2012, 18, 186-192.

94. Choo, C.C.; Harris, K.M.; Ho, R.C. Prediction of lethality in suicide attempts: Gender matters. OMEGA-J. Death Dying 2017. [CrossRef]

95. Williford, M.L.; Scarlet, S.; Meyers, M.O.; Luckett, D.J.; Fine, J.P.; Goettler, C.E.; Green, J.M.; Clancy, T.V.; Hildreth, A.N.; Meltzer-Brody, S.E. Multiple-institution comparison of resident and faculty perceptions of burnout and depression during surgical training. JAMA Surg. 2018, 153, 705-711. [CrossRef]

96. Rodrigues, H.; Cobucci, R.; Oliveira, A.; Cabral, J.V.; Medeiros, L.; Gurgel, K.; Souza, T.; Goncalves, A.K. Burnout syndrome among medical residents: A systematic review and meta-analysis. PLoS ONE 2018, 13, e0206840. [CrossRef]

97. Eckleberry-Hunt, J.; Kirkpatrick, H.; Barbera, T. The Problems With Burnout Research. Acad. Med. 2018, 93, 367-370. [CrossRef]

98. Ho, C.S.; Zhang, M.W.; Ho, R.C. Optical Topography in Psychiatry: A Chip Off the Old Block or a New Look Beyond the Mind-Brain Frontiers? Front. Psychiatry 2016, 7, 74. [CrossRef]

99. Lai, C.Y.Y.; Ho, C.S.H.; Lim, C.R.; Ho, R.C.M. Functional near-infrared spectroscopy in psychiatry. BJPsych Adv. 2017, 23, 324-330. [CrossRef]

100. Ho, R.C.; Cheung, M.W.; Fu, E.; Win, H.H.; Zaw, M.H.; Ng, A.; Mak, A. Is high homocysteine level a risk factor for cognitive decline in elderly? A systematic review, meta-analysis, and meta-regression. Am. J. Geriatr. Psychiatry 2011, 19, 607-617. [CrossRef]

101. Lancet. Violence against doctors: Why China? Why now? What next? Lancet 2014, 383, 1013. [CrossRef]

102. Lo, D.; Wu, F.; Chan, M.; Chu, R.; Li, D. A systematic review of burnout among doctors in China: A cultural perspective. Asia Pac. Fam. Med. 2018, 17, 3. [CrossRef]

(C) 2019 by the authors. Licensee MDPI, Basel, Switzerland. This article is an open access article distributed under the terms and conditions of the Creative Commons Attribution (CC BY) license (http://creativecommons.org/licenses/by/4.0/). 